University of Rhode Island

DigitalCommons@URI

Theses and Major Papers

Marine Affairs

1996

\title{
Applying the Concept of Recreational Specialization to Rhode Island Alliance Anglers
}

\author{
Eric Asadorian \\ University of Rhode Island
}

Follow this and additional works at: https://digitalcommons.uri.edu/ma_etds

Part of the Oceanography and Atmospheric Sciences and Meteorology Commons, and the Social Psychology and Interaction Commons

\section{Recommended Citation}

Asadorian, Eric, "Applying the Concept of Recreational Specialization to Rhode Island Alliance Anglers" (1996). Theses and Major Papers. Paper 280.

https://digitalcommons.uri.edu/ma_etds/280

This Thesis is brought to you for free and open access by the Marine Affairs at DigitalCommons@URI. It has been accepted for inclusion in Theses and Major Papers by an authorized administrator of DigitalCommons@URI. For more information, please contact digitalcommons-group@uri.edu. 
In presenting this thesis in partial fulfillment of the requireents for an advanced degree at the University of Rhode Island, I gree that the Library shall make it freely available for inspection. further agree that permission for copying, as provided for by the spyright Law of the U.S. (Title 17, U.S. Code), of this thesis for cholarly purposes may be granted by the Librarian. It is understood lat any copying or publication of this thesis for financial gain lall not be allowed without my written permission.

I hereby do/do not) grant permission to the URI Library , copy my thesis/dissertation for scholarly purposes.

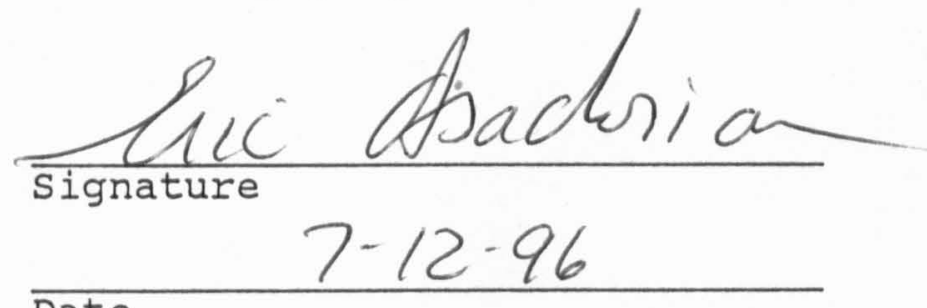
Date 
APPLYING THE CONCEPT OF RECREATIONAL SPECIALIZATION TO RHODE ISLAND ALLIANCE ANGLERS

BY

ERIC ASADORIAN

A THESIS SUBMITTED IN PARTIAL FULFILLMENT OF THE

REQUIREMENTS FOR THE DEGREE OF

MASTER OF ARTS

IN

MARINE AFFAIRS

UNIVERSITY OF RHODE ISLAND

1996 
MASTER OF ARTS THESIS

OF

ERIC M. ASADORIAN

APPROVED:

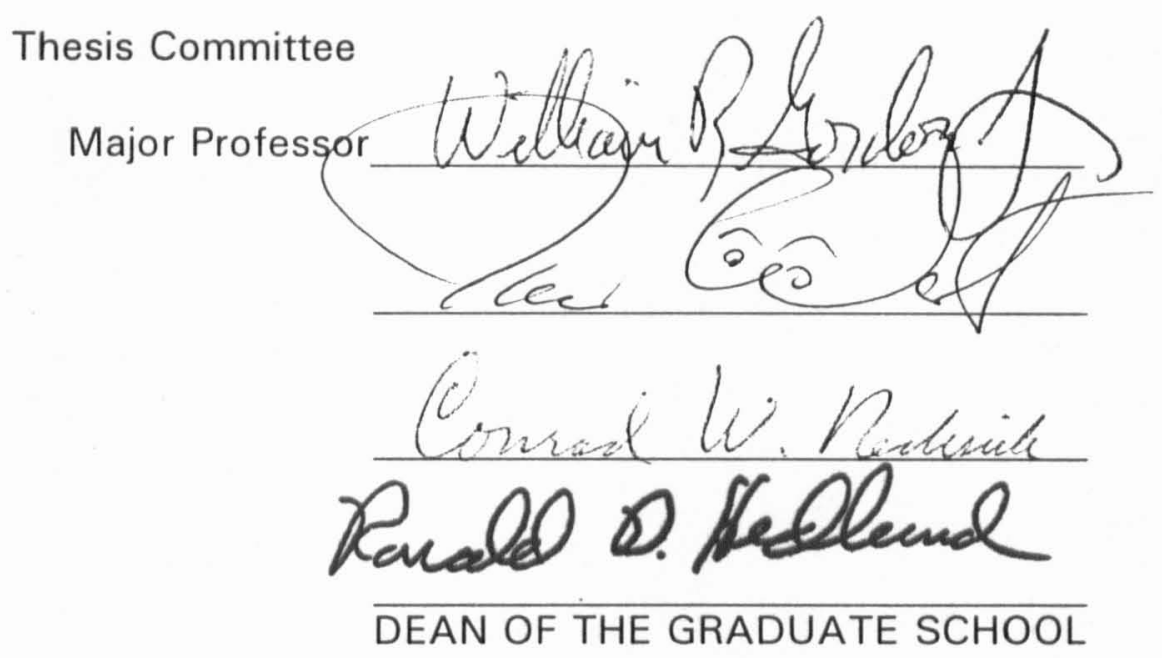

UNIVERSITY OF RHODE ISLAND 


\begin{abstract}
Many recreationally popular marine species of fish are at or near historic lows in terms of their overall numbers. Many of these species, such as cod, summer flounder, winter flounder, and bluefish, are also commercially valuable. Fishery managers must be able to make allocation and management decisions that both protect the resource and maintain user satisfaction. The basis for achieving this goal lies in the understanding of what the users expectations, satisfactions and perceptions are related to their marine recreational fishing experience. It is often the case that a population of anglers are managed as a homogeneous group, with similar characteristics and satisfactions. In fact, recreational anglers are quite different, with many sub-groups that each have their own set of attitudes and expectations regarding their marine recreational fishing experience.

In addition to the economic benefits of marine recreational fishing, their are equally important psychological and physiological benefits associated with recreational fishing. Early studies found stress relief, experiencing natural surroundings, being with friends, developing skills and relaxation as some of the reasons why they participate in marine recreational fishing. Researchers began to study how various sub-groups of angers placed different levels of importance on catch (fish size, numbers of fish caught, keeping fish to eat) and non-catch (relaxation, for the sport, enjoying nature) motives for participating in marine recreational fishing. These sub-groups could be charter boat anglers, shore-based anglers, anglers who pursued certain species of fish, or anglers with different levels of specialization.
\end{abstract}


Previous research has shown that participants in a recreational activity are spread in a continuum, at one end are the least specialized and at the other the most specialized. More specialized anglers may seek more specific recreational fishing activities than less specialized anglers. They may be more willing to cooperate with restrictive management decisions and convince less specialized anglers to support these measures. The activity of recreational fishing is usually more central to a highly specialized angler than a less specialized one. The highly specialized angler participates in fishing more often, reads fishing related material, participates in fishing tournaments, and is more likely to be a member of a fishing club than less specialized anglers.

The objective of this thesis was to refine the methodology which discriminates marine recreational anglers by their revealed level of recreational specialization. A subsidiary objective was to create a data base of Rhode Island club anglers which provides the first comprehensive evaluation of their characteristics.

Surveys were distributed to various fishing clubs around the state. These clubs were all members of the Rhode Island Alliance. The survey solicited information regarding the importance the angler placed on various motivational statements as to why they participate in marine recreational fishing. Three variables (avidity, monetary investment, years of fishing experience) were selected as a means of segmenting the study population into two sub-groups, one highly specialized the other less specialized. For each variable, those anglers who fell more than one standard deviation above the mean were considered highly specialized and their responses to the various motive statements were compared to the remaining anglers who were considered less specialized. It was hypothesized that the 
highly specialized anglers would place greater importance on the sport and challenge motives (for the sport, developing fishing skills, a fishing trip can be successful even if no fish are caught) for marine recreational fishing than less specialized anglers. It was also hypothesized that the highly specialized anglers would place less importance on the harvest and consumption motives (keeping your catch, bringing fish home to eat, catching many fish) for recreational fishing than less specialized anglers.

The variables avidity and years of experience proved to be excellent discriminators of recreational fishing specialization. Anglers in the highly specialized category of each of these variables placed greater importance on the sport and challenge motives and less importance on the harvest and consumption motives for recreational fishing. The variable for monetary investment failed to produce any significant results.

The management utility of this study can be derived from understanding that recreational anglers are a diverse group, with different perceptions, expectations, motivations and satisfactions with their recreational fishing experience. With this knowledge, fishery managers can better project how their constituents will react to various management measures. With the proper understanding of the resource and the users of the resource, managers can implement regulations that both protect the resource and maintain user satisfaction, which is a desired goal of any management plan. 


\section{ACKNOWLEDGMENTS}

I would like to thank my major professor Dr. William Gordon for his input and guidance in the creation and development of one of the most challenging and at times frustrating academic endeavors I have undertaken. I would also like to thank Dr. Neils West and Dr. Conrad Recksiek for their comments and suggestions and Dr. Farhad Atash for taking the time to chair my defense. Finally, I would like to thank my wife Jamie for being so patient and understanding. Hopefully this patience and understanding will continue while I search for a job! 
ABSTRACT …..................................................................................... ii

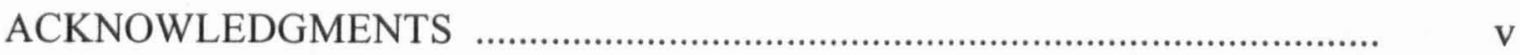

TABLE OF CONTENTS ......................................................................... vi

LIST OF TABLES …................................................................................ viii

\section{CHAPTER}

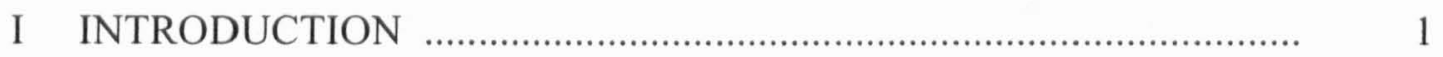

Statement of the Problem ...................................................................

Nature of the Problem …............................................................ 5

Importance of the Problem ........................................................... 6

Fisheries Management in the United States ….................................... 7

Funding for Recreational Fishing .............................................. 9

State Marine Fisheries Management ........................................... 10

Current Status of Marine Recreational Fisheries Management ...... 11

Objectives ................................................................................. 13

II LITERATURE REVIEW ........................................................... 14

Angler Motivation ........................................................................... 14

Recreational Fishing Satisfaction .................................................... 15

Importance of Catching Fish ...................................................... 18

Recreational Angler Specialization................................................ 19

The Social Worlds of Recreational Fishing ............................... 24

Research Opportunities ............................................................ 26

III METHODOLOGY ….................................................................... 28

Research Hypotheses ............................................................... 28

Basis of the Hypotheses within the Literature ............................ 29

Avidity .............................................................................. 29

Monetary Investment ................................................................... $\quad 30$

Years of Fishing Experience ................................................. 31 
Assumptions ………………………......................................... 31

Study Population …………………………………………........... 31

Data Collection .............................................................................. 32

Validity of The Survey Instrument ……………………………........ 32

The Survey Instrument ................................................................. 33

$\begin{array}{lll}\text { CHAPTER Page } & \text { Pat }\end{array}$

IV SURVEY RESULTS _...................................................................

Motive Statement Responses ......................................................... 37

Comparison with other Similar Studies ............................................. $\quad 40$

Comparison with other Fishing Clubs …………………................... 42

Survey Difficulties ...................................................................... 45

$\mathrm{V} \quad$ TESTING THE HYPOTHESES ……………………....................... 46

Examining the Variable AVIDITY ..................................................... 49

Results of Testing the Variable AVIDITY .................................... 51

General Analysis of the Variable AVIDITY ………….................. 53

Examinig the Variable INVEST ...................................................... 53

Results of Testing the Variable INVEST ..................................... 56

General Analysis of the Variable INVEST …………………….... 56

Creating the Variable Years ……………………………….......... 57

Results of Testing the Variable YEARS ……………………...... 59

General Analysis of the Variable YEARS ....................................... 60

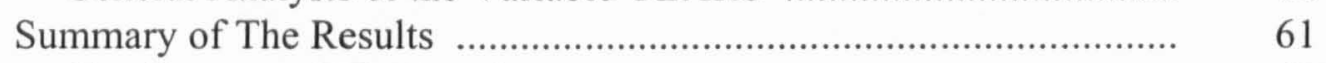

Significance of The Results ........................................................ 62

Management Implications …………………………...................... 64

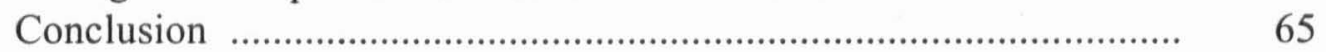

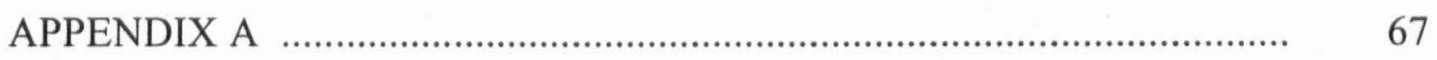

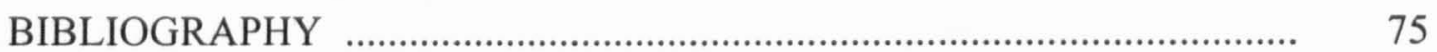




\section{LIST OF TABLES}

Table

Page

1 Frequency Distribution of Respondents Years of Fishing Experience 35

2 Frequency Distribution of Respondents Ages and Level of Avidity 36

3 Motive Statement Responses 38

4 Mean Angler Satisfaction Responses 39

5 Comparison with Similar Studies

6 Alliance and Gulf Coast Mean Responses

7 Levels of Significance for a one-tailed test at $\mathrm{df}=120$ 48

8 Testing the Variable AVIDITY 50

9 Testing the Variable INVEST $55-56$

10 Testing the Variable YEARS 58 


\section{CHAPTER I}

\section{INTRODUCTION}

The question of why people go recreational fishing may seem trivial in nature. A logical and likely response would be to catch fish. This question was first addressed in the literature in the early 1970’s (Spaulding 1970; Bryan 1972; Moeller and Engelken 1972; Driver and Knopf 1976). These academic and applied research efforts provided valuable insight for current fishery managers to better understand the motivations of why people go fishing. Understanding the factors for angler participation is important for three reasons (Driver 1985; Fedler and Ditton 1994). First, there is the need to explain and forecast angling behavior. Nothing is more fundamental to understanding angling behavior than the factors that prompt it. Second, it is important for recreational fishery managers to be able to isolate those factors that influence people to go fishing and examine how those factors vary between different angler groups. Third, gaining an increased ability to understand the basic components of fishing motivation and satisfaction may help contribute to the development and implementation of more effective recreational fishing programs and services (Driver 1985). By failing to recognize essential angler motivations, managers may be incapable of providing an appropriate balance of angling opportunities to fully meet public angling needs. As will be discussed later, state fishery managers are not always convinced of the advantage to having this type of information for the management of recreational fisheries. 
As may be expected, recreational anglers are not homogeneous in terms of their motivation, satisfaction, expectation or perception. Research has demonstrated that recreational anglers can be segmented into various sub-groups, each with their own distinct preferences, motives, satisfactions, and expectations (Ditton 1977; Graefe 1981; Ditton and Holland 1984; Ditton and Holland 1986; Fedler and Ditton 1986; Loomis and Ditton 1987; Chipman and Helfrich 1988; Ditton et al. 1990; Hahn 1991; Ditton et al. 1992; Gigliotti and Peyton 1993). Anglers place varying levels of importance on catching, retaining or eating fish. Similarly, other anglers derive satisfaction solely from the recreational experience.

Recreational fishery managers must be able to recognize the various sub-groups of anglers they regulate and understand how imposing various regulations can impact fishing satisfaction. In their management activities, fisheries managers typically monitor the availability and biological success of numerous commercially and recreationally desired species of fish. Managers may use several conservation measures to regulate the recreational anglers. These tools include seasonal restrictions, bag limits, size limits, gear limits and fishery closures. When imposing regulations which constrain anglers, managers must be able to weigh the benefits to the fishery with the potential harm to the users. Often, impacts to users are manifested in a reduction of overall participation in a recreational fishery. Obviously, if anglers do not participate in recreational fishing, the benefits which recreational fishing provide, be it economic or social, will not be realized. With a comprehensive understanding of the recreational fishing experience, in terms of motivations sought and satisfactions received, fishery managers may make policy decisions 
that maximize angler satisfaction and minimize resource-user conflicts (Chipman and Helfrich 1988; Hahn 1991).

Fisheries managers must understand the fundamental concept of specialization (Bryan 1977) to fully recognize the social dimensions of contemporary angling (Hahn 1991). Angler specialization may be the key determinant of angler's perceptions, expectations, motivations, satisfactions, and the meanings they attach to fishing (Bryan 1976, 1977, 1982, 1983; Hahn 1991). Application of this concept in fisheries research should contribute to recreational fisheries managers understanding of angling as a social behavior.

Recreational fisheries are often managed using only biological and economic data. The social data needed to complete a comprehensive analysis of recreational fisheries is often overlooked by fishery managers due to a lack of funds to collect it, or the belief that it is not important to the management process. The challenge for the researcher is to be able to gather and analyze this social data in a way that is managerially relevant. Utilizing the recreational specialization framework should facilitate the means for fishery managers to better understand and project angler behavioral responses to various fishing conservation measures they seek to implement.

Bryan (1982), Hahn (1991) and Hendee (1974) believe that when making policy decisions and allocating scarce resources, managers should favor recreational specialists. Recreational specialists tend to be respected among their fellow recreationalists as opinion leaders and can be used to convince less specialized recreationists of the importance of supporting and abiding by management regulations (Hahn 1991). When confronted with conflicting user expectations, managers should provide the limited but specific experiences 
and expectations specialists require and direct less specialized participants to alternative resources that will meet their more general expectations.

\section{STATEMENT OF THE PROBLEM}

Many of the species of fish which recreational anglers in the Northeast target are heavily overfished as defined by the National Marine Fisheries Service (U.S. Department of Commerce 1994). As a result, the number of fishery conservation measures imposed on recreational fishermen, such as increased minimum sizes and bag limits, has increased significantly since 1986 as a result of actions by state fishery agencies, the Atlantic States Marine Fisheries Council (ASMFC) and regional fishery management councils (see the discussion in the next section). Presently, allocation decisions are based on biological and catch per unit effort data. These data are typically used in a fashion that portrays anglers as a homogeneous group. Marine fishery managers generally do not have enough data on expectations and satisfactions of the various sub-groups of recreational anglers to factor them into allocation decisions. If fishery managers desire to achieve the benefits of their conservation measures, they will need to better understand the diversity of the recreational fishing constituency they manage.

This thesis examines the relative importance and extent to which specific recreational angling motivations differ between highly specialized marine recreational anglers and less specialized marine recreational anglers. In order to evaluate these relationships, the present research challenge is to develop and implement techniques to discriminate angling sub-populations by their respective levels of angling specialization. 


\section{Nature of the Problem}

Research by Bryan (1977), Chipman and Helfrich (1988) and Hahn (1991) identified that the level of angler specialization may be the key determinant in segmenting anglers into managerially relevant groups. Being able to segment an angling population into separate groups based on levels of angling specialization is important in a relationship that as angler specialization increases, angler satisfaction becomes closely linked to the fishery resource. The sport of pursuing and catching fish, but not necessarily harvesting fish becomes increasingly important (Hendee 1969; Bryan 1977, 1982, 1983; Gill 1980; Graefe 1981; Manfredo and Anderson 1982; Loomis and Ditton 1987; Chipman and Helfrich 1988; Palmer 1988; Hahn 1991). As a result, resource conservation, especially habitat protection, becomes a primary concern and anglers increasingly favor strict enforcement of game laws and are more willing to cooperate with management decisions that reduce creel limits and increase minimum length limits to enhance the resource (Bryan 1977, 1983; Gill 1980; Chipman and Helfrich 1988; Hahn 1991).

Although small in number relative to the general fishing population, it is believed that highly specialized recreational anglers spend more money on fishing and fishing related industries, catch more fish, and have greater political and social involvement in recreational fishing related activities than less specialized activities (Ditton et al. 1992). Consequently, the overall impact of specialized anglers to a recreational fishery in a given area may be substantial. Clearly, if fishery managers better understand the motives and expectations which highly specialized anglers seek, they may create conditions which can maximize their recreational fishing satisfaction. 


\section{Importance of the Problem}

Sport fishing is an essential economic component, with numerous multiplier effects, in the United States. The Sport Fishing Institute estimated that saltwater anglers fishing in the Northeast spent over one billion dollars to catch fish in 1985 with about $\$ 360$ million being spent in New England and $\$ 720$ million in the mid-Atlantic (the most recent year for which an expenditures survey was conducted) (U. S. Department of Commerce 1993, 33). In addition, over $\$ 400$ million was spent on food and lodging during fishing trips.

Marine recreational fishing in Rhode Island is an essential part of the state's economy. Approximately 350,000 people fish in Rhode Island's waters each year for a total of 1.2 million fishing trips (Williams and Corey 1994). These anglers spend nearly $\$ 100$ million each year on fishing equipment, including tackle, gas, boats, and repairs, not to mention food and lodging (Williams and Corey 1994).

The relative size of the recreational harvest is considerable. The estimated recreational catches of many fish species harvested off the northeastern United States, including black seabass, bluefish, striped bass, summer flounder, weakfish, and pelagic sharks, may approach or exceed their respective U.S. commercial landings by weight. (U. S. Department of Commerce 1993, 28). In 1992, recreational anglers caught roughly 100 million marine finfish during more than 19 million fishing trips in the Northeast Region of the United States (U. S. Department of Commerce 1992, 35).

Another indirect challenge for marine recreational fishery managers is to promote the economic and social benefits recreational fishing provides to society. All too often 
individuals involved in fishery management, be it state agency personnel, academicians, or the members of the recreational fishing industry, gather social and economic information on recreational fishing in such a way that only reflect the needs and attitudes of the "average" recreational angler who in reality does not exist as opposed to the needs and attitudes of a diverse recreational fishing constituency (Sport Fishing Institute 1993, 3). Too few research and management efforts have been conducted which classify anglers into populations with distinct needs and attitudes. Further, even fewer efforts have been made to understand the expectations of these distinct populations. What is commonly overlooked is that fisheries management means managing people as well as fish.

State recreational fishery managers typically do not identify the various sub-groups of anglers in their jurisdiction. Further, fishery managers do not execute studies which identify those angler groups which exhibit high levels of recreational fishing specialization. Many researchers have argued that these individuals or groups should be solicited for input and advice on the management of the recreational fisheries in which they participate. More importantly, these researchers believe that management decisions should be tailored to suit the specialized needs of these anglers to ensure their continued support and commitment to the sport and resource. They feel that only in this way can the management of recreational fisheries provide all the social and economic benefits that it is capable of.

\section{FISHERIES MANAGEMENT IN THE UNITED STATES}

The United States commercial and recreational fishery resources are managed under the Fishery Conservation and Management Act of 1976 (FCMA), ammended in 1981 as 
the Magnuson Fishery Conservation and Management Act (16 U.S.C. Codes Section 1801-1882). This law was enacted in response to the seriously depleted condition of commercially and recreationally important species of fish due to overfishing from foreign fleets near the United States. Congress concluded that a national program was necessary to prevent further overfishing, to ensure conservation, and to rebuild the nation's fishery resources. Since 1976, the U. S. has controlled its fishery and other natural resources from three nautical miles from the shore out to a distance of two hundred nautical miles seaward of the baseline. This area is called the Exclusive Economic Zone (EEZ). Coastal states have jurisdiction over the waters extending three nautical miles seaward of the baseline.

Under FCMA, management of fishery resources is accomplished by the creation of fishery management plans (FMP's). These plans are developed by regional management councils and approved by the secretary of the Department of Commerce. The objective of the management policy under FCMA was to harvest fish at an Optimum Yield (OY). The OY level of harvest would provide the greatest overall benefit to the nation. The concept of OY was unique because it called for relevant social and economic factors to be considered in addition with the biological factors to be considered when establishing harvest regulations. Under FCMA guidelines, the regional councils were required to develop management plans for each identifiable fishery unit. One of the objectives of the regional council was to allocate OY catches between domestic commercial fishermen and recreation anglers. These councils may utilize a diverse array of conservation measures in their FMP's, including limiting gear, effort levels, and new entry into the fishery. The 
council is under the directive of the National Marine Fisheries Service (NMFS) which is part of the National Oceanic and Atmospheric Administration (NOAA), within the Department of Commerce.

NMFS Marine Recreational Fisheries Policy established in 1981 stated that their first priority was to develop and maintain a comprehensive marine recreational fisheries data acquisition and analysis system. The data were compiled and are distributed through regional manuals called the Marine Recreational Fishery Statistics Survey. The data contained in these manuals contains estimates of participation, effort, and catch by recreational anglers in the marine waters of the United States.

\section{Funding for Recreational Fishing}

In 1950, Congress passed the Federal Aid in Fish Restoration Act (16 U.S.C. 777$777 \mathrm{k}$ ) which provided a way to finance management and conservation initiatives for recreational fisheries. Better known as the Dingell-Johnson Act, it placed excise taxes on sport fishing tackle to support sport fisheries management in individual states. In 1986, the act was expanded, through the Wallop-Breaux Amendment, to apply the excise tax to all fishing equipment and to direct receipts from such sources as duties on imported fishing gear and pleasure craft to support state coastal fisheries management efforts. Annually, the revenues are directed into the Wallop-Breaux Trust Fund and are distributed by formula according to each state's recreational fishing activity. States are required to direct a percentage of their funding to boating access to public waters, and coastal states must support marine, as well as freshwater, fisheries enhancement. 
One of the problems with the Wallop-Breaux program is that many anglers are not aware of the program and the benefits the program provides. Many feel that states have not done a very good job of informing and involving anglers in state Wallop-Breaux programs (Sport Fishing Institute 1993, 2). This is unfortunate because the recreational angling public, whether they are organized in clubs or individual fishermen, can be a state fish and game department's most valuable ally and strongest supporter (Sport Fishing Institute 1993, 3). States should adopt a strategic plan which clarifies the goals and objectives that are to be achieved through the Wallop-Breaux monies. It is imperative that this planning process involve the active participation of the recreational angling community and the sport fishing industry, so that their needs and expectations are completely integrated into the strategic plan (Sport Fishing Institute 1993, 3). In creating these types of plans, fishery managers should utilize the information in studies such as this as an aid in allocating monies and resources between the various groups of fishermen in their state.

\section{State Marine Fisheries Management}

The Atlantic States Marine Fisheries Commission (ASMFC) was established in 1942 in order to coordinate the multistate management of Atlantic coastal fishery resources. All fifteen states of the Atlantic coast are members. The creation of the ASMFC was important in terms of facilitating the proper management of fish species which migrate through multiple state waters. Without the ASMFC, these species would literally be at the mercy of the regulations of each individual states, many of which varied considerably. 
Initially, the commission was simply an advisory body that depended on the cooperation of member states to collectively support those fishery management programs that would benefit the region and nation as a whole. The ASMFC initiated the development of interstate management plans which focused on the entire stock of a species, not just that segment of the stock that happened to frequent a states waters. However, the commission had no binding authority to require the member states to adopt any of its resolutions and recommendations.

The commission's status changed considerably after the passage of the Atlantic Striped Bass Conservation Act of 1984 (The Striped Bass Act) (98 Stat. 3187). The striped bass was highly valued to both commercial and recreational fishermen. It is regarded by some as the most important marine finfish in the mid-Atlantic and Northeast. The striped bass populations began a steady decline in the early 1970's which continued through the early 1980 's. Due to the migratory nature of striped bass, it is common for these fish to pass through several state's waters during their seasonal migrations. Typically, these states have varying size and bag limits for both recreational and commercial catches. Until the 1980's ASMFC member states had never adopted a proposal for cooperatively managing striped bass populations. Sensing a potential collapse of the fishery, legislators submitted several bills to Congress. The Atlantic Striped Bass Conservation Act of 1984 was enacted in response to these concerns. Basically, the Act gave the commission the power to secure federal government assistance in sanctioning a member state which fails to comply with the commission's FMP's. If a 
state failed to comply with the striped bass FMP, that state would have its striped bass fishery closed.

\section{Current Status of Marine Recreational Fisheries Management}

Maine, New Hampshire, Massachusetts, Rhode Island and Connecticut are member states of the New England Fishery Management Council which is responsible for creating and implementing the regions FMP's. At the present time (spring 1996) a total of five amendments have been developed or are proposed, all of which are related to recreationally important species (summer flounder, winter flounder, bluefish, and striped bass). Additional possession limits, size limits, quotas, and seasonal and area closures have been recommended to further reduce the harvest of these species. NMFS has turned over most of the management and allocation decisions for fish in the Northeast that occur primarily in the states territorial waters (out to three nautical miles from shore) to the ASMFC, leaving NMFS the managing body for species of fish which occur primarily in the EEZ (exclusive economic zone which extends from the end of the coastal state's territorial sea out to two hundred miles from shore). Importantly, the abundance of bluefish, summer flounder, and other recreationally important marine fish species in the Northeast region are at or near historic lows (U.S. Department of Commerce 1994). This may mean more restrictive measures will be implimented in the near future.

Presently, the ASMFC makes allocation and restriction decisions based purely on biological data. A stock assessment committee gathers all the relevant biological data on the species in question. This committee then submits a report stating the status of the stock to a technical sub-committee. The sub-committee reviews the report and may 
request the committee to address certain issues. A final report is drafted and presented to a management board. The management board consists of state fish and wildlife directors from all the states who have jurisdiction over the species in question. Other members of the management board are United States Fish and Wildlife service managers, state fishery managers (only those who have jurisdiction over the species in question), as well as the director of the ASMFC. The management council takes all the information from the reporting parties and recommends management measures. These measures are presented to the full commission which meets twice a year. The full commission consists of state fish and wildlife directors and state fishery managers from all states in the ASMFC. The full commission is the body which approves or rejects any FMP.

\section{OBJECTIVE}

The objective of this thesis is to refine a methodology which discriminates marine recreational anglers by their revealed level of recreational specialization. This research will provide a comprehensive description of the study population which may accommodate Rhode Island recreational fishery managers with important information regarding the characteristics of the resource users they manage. With the findings of this study, Rhode Island recreational fishery managers may better understand why it would be useful to seek out local marine recreational fishing clubs thereby accessing a rich source of information that can be quickly and inexpensively obtained. 


\section{CHAPTER II}

\section{LITERATURE REVIEW}

\section{ANGLER MOTIVATION}

Typically, recreational fisheries are managed to provide recreational anglers with opportunities to catch fish. Clearly, anglers go fishing in places where they believe fish are, and where they may be caught. Research has shown, however, that there are diverse and complex reasons why people go fishing other than "to catch fish."

Early studies of recreational fishermen identified the various aesthetic and social variables which influence angler satisfaction. Spaulding (1970) proposed that a fundamental element in understanding recreation is comprehending man's "need for variety." Spaulding examined how anglers, from different occupations, used fishing as a means of relieving stress. He found that Rhode Island boat-using fishermen registered less tension and more relaxation during sport fishing than during their occupational activity. Moeller and Engelken (1972) found that New York freshwater anglers identified natural environmental factors such as water quality, natural beauty, and privacy while fishing to be important to their overall enjoyment of a typical day trip of fishing. The size or the number of fish caught was not listed as important to their overall enjoyment of their fishing trip. Knopf et. al. (1973) suggested that recreational fishermen are strongly motivated by four unmet needs. Temporary escape, achievement, exploration, and experiencing natural surroundings were found to be of paramount importance in an anglers desire to "go fishing". Driver and Knopf (1976) concluded that experiences that 
recreational anglers seek are based on the outdoor experience, developing angling skills, being with friends, challenge, relaxation, learning about nature, taking a trophy fish, testing equipment, escaping the daily routine, and sharing fishing skills. Each of these experiences are probably shared and realized by all fishermen, but some are relatively more important to certain fishermen than others. The final social products from a recreational fishing experience include both satisfactions (e.g., catch, relaxation, exercise) and benefits (e.g., improved health).

Hendee and Bryan (1978) reviewed fifty six hunting, fishing, and other recreation activities and found several commonly mentioned motives for participating in these activities. The motives most frequently mentioned for fishing were; 1) experiencing nature, 2) relaxation, 3) escape, and 4) companionship. Catch was only mentioned in three of the studies as an important motive.

Fedler (1984) combined previous findings to determine the most common motives for fishing. Results of his study concluded that recreational fishermen placed a high importance on relaxation, interaction with nature, social interaction, and the escape from daily routines.

\section{RECREATIONAL FISHING SATISFACTION}

A primary research question of the early body of literature was how to define and evaluate recreational fishing satisfaction. Hendee's (1974) multiple satisfaction approach to game management provided a good understanding of the importance of identifying the diversity in recreational activities such as fishing. Hendee noted that recreational 
resources offer people the opportunity for a range of experiences which, in turn, gives rise to various human satisfactions. These multiple satisfactions may then lead to benefits, which is an ultimate goal of recreation-resource management. The desired goal of game management should be to produce desired and worthwhile human satisfactions and experiences that in turn may result in a variety of physical, psychological, personal and economic benefits to people.

The implications this approach has for recreational fisheries management is that it demonstrates that for some sportsmen, relaxation, social interaction, and being in natural surroundings may be the most important outcomes of the fishing experience. By understanding the importance of these and other aspects of the recreational fishing experience, managers could provide for these experiences while implementing catch and size limits and still maintain relatively high levels of angler satisfaction.

It is important to understand the differences between angler motivations and angler satisfaction. The two terms should not be used interchangeably. Dawson and Wilkins (1990) defined angler satisfaction as the sum of the satisfying experiences of the particular fishing activity (relaxation, catch, companionship, enjoying nature) less the dissatisfying experiences (poor catch, poor weather, restrictive regulations).

Ditton (1981) utilized Lawler's Discrepancy Theory (1973) as a possible means to explain recreational fishing satisfaction. The Discrepancy Theory suggests that satisfaction is determined by the differences between the outcomes an individual thinks they should receive and the outcomes that person actually received. Overall angler satisfaction in any situation is influenced by the sum of the discrepancies that exist for each 
facet of the situation. Fedler (1984) added that motivations for fishing provide the basis from which evaluations of individual components of the experience are made. Graefe and Fedler (1986) examined the extent to which total satisfaction can be explained in terms of a summation of satisfaction with separate elements of the experience. The study concluded that overall angler satisfaction is influenced most directly by subjective evaluations of specific aspects of the experience such as the desire to catch more or larger fish and catching the targeted fish. Situational outcomes of the experience such as numbers and size of the catch, crowding, and weather tend to influence overall satisfaction in a more indirect manner as they are filtered through the various subjective evaluations.

Spencer and Spangler (1992) evaluated the relationship between angler expectations and fishing satisfaction. They found that both trip and fishing satisfaction decreased as expectations for larger fish increased. They concluded that anglers with more realistic expectations would experience greater fishing satisfaction. Hudgins and Davies (1984) found that satisfaction was a function of the anglers expectations for success. Anglers who did not expect to catch many fish had just as high fishing trip satisfaction ratings as anglers who expected to, and caught, many fish.

Clearly, the notion of angler satisfaction is nebulous and complex. The literature has found that angler satisfaction is the result of a multitude of human experiences, expectations, perceptions and realizations. Each of these factors contribute in their own way and with their own level of importance in determining angler satisfaction. 


\section{IMPORTANCE OF CATCHING FISH}

The literature pertaining to why recreational anglers participate in fishing places consumption and retention of the catch below the recreational experience in importance (Knopf et al. 1973; Hendee 1974; Hampton and Lackey 1976; Ditton and Holland 1984). Matlock et al. (1988) challenged this premise. The study examined the reactions of East Matagorda Bay, Texas, anglers after a massive natural fish kill. The Texas Parks and Wildlife Commission responded to the kill by eliminating bag limits of red drum and spotted seatrout for East Matagorda Bay recreational anglers. The affected anglers were sufficiently upset and opposed the commission's ruling. Matlock et al. (1988) concluded from this reaction that recreational anglers placed a greater importance on the catching and retaining of fish than the literature suggests.

The ensuing academic debate provided an excellent opportunity to reinforce many researchers views on the importance of the catching and retaining of fish. Ditton and Fedler (1989) concluded the main reason for the angler's opposition was that they were the only angler group in the region who had to bear such a burden as a zero bag limit. Other angler groups experienced only a reduction in bag limits. Also, Matlock et al. (1988) lacked any testable hypotheses and provided no data to support their assertion. The key omission they made was that they assumed that the response by the East Matagorda Bay anglers could be expected by any angler population. They failed to recognize that recreational anglers are not a homogeneous group. Important to the needs of fishery managers, Ditton and Fedler (1989) noted that there are unique sub-groups of anglers who have different attitudes and motivations for fishing and seek different 
environments and experiences. Each of these sub-groups have unique expectations which contribute to their overall fishing satisfaction. Peyton and Gigliotti (1989) contended that the literature defended the importance of fish retention, but noted this concern was usually of lower priority to anglers.

The East Matagorda Bay experience solidified previous research which asserted that there are many reasons why people go fishing, and different groups of anglers place different levels of importance on the catch and non-catch motives for recreational fishing. Importantly, any attempt to forecast angler responses to management decisions must be based on an analyses of the angler segment being affected and not the general angling population. With a better understanding of angler motivations and how they relate to angler behavior, managers can more easily anticipate angler responses to specific changes in management actions and ensure fishing experiences being provided meet angler needs (Fedler and Ditton 1994).

\section{RECREATIONAL ANGLER SPECIALIZATION}

The marine recreational fishing literature has expanded beyond the basic concern of angler motivations and satisfaction. Important research efforts have focused on classifying recreational anglers into sub-groups, each based on similar characteristics (Bryan 1977; Ditton 1977; Graefe 1981; Ditton and Fedler 1986; Loomis and Ditton 1987; Chipman and Helfrich 1988; Ditton et al. 1990; Hahn 1991; Ditton et al. 1992; Spencer and Spangler 1992; Spencer 1993; Fedler and Ditton 1994). The ongoing challenge for the researcher is to identify ways to segment the angling population into managerially relevant sub-groups. Ditton (1977) believed that once sub-groups have been defined, their 
perceptions of local problems, preferences for management alternatives, and degree of satisfaction with their recreational fishing experience can be accurately evaluated.

Findings of research into angler satisfaction have suggested that instead of formulating generalizations to be applied widely to all sport anglers, managers should take a market segmentation approach which recognizes that the fishing public is made up of diverse and distinct subgroups. Comparisons of these angling subgroups often reveal differences in the relative importance they place on satisfaction elements of their recreational fishing experience (Peyton and Gigliotti 1989).

The following discussion will highlight the evolution of the recreational specialization concept in marine recreational angling from the 1970's to the present. The level of a recreational anglers specialization has been found to be a useful and important tool in classifying anglers into subgroups. Bryan (1977) examined recreational freshwater trout anglers with different levels of recreational specialization. Bryan believed the specialization dimension may be a significant tool in understanding the behavior and attitudes of these sportsmen. Bryan defined angler specialization as "a continuum of behavior from the general to the particular reflected by equipment and skills used in the sport and activity/setting preference." Bryan classified trout anglers into four groups, each group shared similar participation levels and technique and setting preferences. The four groups were:

1. Occasional Fishermen- those who fish infrequently because they are new to the activity and have not established it as a regular part of their leisure, or because it simply has not become a major interest.

2. Generalist- fishermen who have established the sport as a regular leisure activity and use a variety of capture techniques. 
3. Technique Specialists- anglers who specialize in a particular method, largely to the exclusion of other techniques.

4. Technique-Setting Specialists- highly committed anglers who specialize in method and have distinct preferences for specific water types on which to practice the activity (Bryan 1977, 178).

Bryan's study revealed four distinct conclusions. First, anglers tended to move into more specialized stages over time with an increasing commitment to the sport. The more specialized angler relies on a high level of knowledge and commitment to a variety of angling pursuits as an out-growth of high time and skill commitment to the sport. Second, the study found that the most specialized fishermen joined a leisure social world, or a group of fellow anglers holding similar attitudes, beliefs, ideologies, and engaging in similar behavior. This social world serves as a source of identification for these anglers. Third, as the level of angling specialization increases, attitudes and values about the sport change. Focus shifts from consumption of the fish to preservation and emphasis on the nature and setting of the activity. Fourth, the values attached to specialization are inexorably linked to the properties of the resource on which the sport is practiced. As the level of angling specialization increases, resource dependency increases. Bryan found that specialists desired a setting that facilitated a degree of control for the angler so as to enable them to determine the difference between skillfully catching fish or being lucky. For a specialized trout fishermen, satisfaction may come from knowing the reason they caught that one trout was because of careful study of the stream and perfect placement of the bait rather than catching their limit. 
The management implications of Bryan's work follows that a framework for forecasting and interpretation of what different sportsmen constituencies are seeking in the outdoors is a necessary first step in effectively managing recreational fishing. Social science researchers identified the utility of this specialization framework and began to refine it.

Graefe (1981) found that classifying anglers according to their level of participation (avidity) was useful in determining different levels of specialization. The study hypothesized that fishermen at varying levels of participation tended to seek different types of experiences. More avid anglers generally attached greater importance to the challenge and sport associated with the fishing experience. Fishermen in low participation categories placed greater importance on catching fish to eat, catching at least something, and catching a lot of fish than anglers in the high participation category. Other environmental or personal reasons for fishing remained relatively similar across the various levels of participation. By understanding what is important to identifiable segments of the fishing population, fishery managers and scientists may be able to better project how these segments will be differentially impacted by various allocation schemes and fishing regulations.

Chipman and Helfrich (1988) concurred with Bryan (1977). They concluded that fishing frequency should be used along with resource dependency, investment in fishing, and centrality to one's lifestyle, as indicators which differentiate the level of specialization among anglers. They believed that using fishing frequency as one dimension and combining the others into a second dimension would lead to more manageable analysis 
techniques to partition angler subgroups. They added that the recreational specialization framework can provide a logical means of identifying angler sub-groups and of learning how these groups view the fishery resource, the angling experience, and harvest allocation decisions.

Hahn (1991) observed that recreational anglers could be classified along a specialization continuum similar to Bryan (1977). The continuum would range from the occasional angler, generalist, species specialists, to the advanced species specialist. Hahn believed that the extent of species specialization, frequency of fishing, investment in angling, years of experience, and centrality of fishing to one's lifestyle are indicators of specialization that consistently discriminate among angler types. As angler specialization increases, angler satisfaction is more closely linked to the fishery resource. The catching of fish, not necessarily the harvesting of fish, takes on increasing importance to the more specialized angler.

It is believed that highly specialized anglers tend to seek specific recreational fishing experiences while less specialized anglers do not have particular preferences and may be content with a variety of outcomes. Highly specialized anglers may be more willing to cooperate with management decisions that reduce creel limits and increase minimum length limits. As opinion leaders among their peers, highly specialized anglers may be solicited by managers to convince less specialized anglers of the importance of abiding by restrictive regulations. Many researchers have argued that when recreational fishery managers make policy decisions in allocating scarce resources, they should favor the more specialized angler (Hendee 1974; Bryan 1982; Hahn 1991). The more specialized angler 
will have a specific or a narrow range of potential experiences while less specialized (generalists) anglers may not be so demanding and be satisfied with a wider range of alternative fishing experiences. The result will be greater aggregate user satisfaction and less user conflict (Hahn 1991).

\section{The Social Worlds of Recreational Fishing}

Ditton et al. (1992) applied the recreational specialization framework of Bryan (1977) to a model of social leisure worlds. Ditton's work re-conceptualized recreational specialization into a process by which 1) recreation social worlds and subworlds segment and intersect into new recreation subworlds and 2) the subsequent ordered arrangement of these subworlds and their members is ordered along a specialization continuum. At one end of the continuum is the least specialized subworld and its members. At the other end is the most specialized subworld and its members.

Strauss (1978) defined a social world as an internally recognizable constellation of actors, organizations, events and practices which have coalesced into a perceived sphere of interest and involvement for participants. Each social world has at least one primary activity (in this case fishing), recognizable locations where the activity occurs (near or on water), a certain technology (fishing equipment) and organizations that evolve to further one or more aspects of the social world. It is important to note that the social world model is conceptual in nature and its definition is by no means rigid. The social world of sport fishing is larger than its groups or organizations; it is not defined or delimited by formal boundaries, membership lists or spatial territory; and lacks a powerful centralized 
authority structure. Social worlds must be viewed as part of a social organization which is diffuse and amorphous in character (Ditton et al. 1992).

Bryan (1977) defined angler specialization as being reflected by the equipment and skills used in the sport and activity setting preference. Since specialization is both defined and measured by the same terms, the definition is also an explanation of specialization.

Ditton et al. (1992) categorized specialization according to an anglers level of participation, which has no relationship to equipment used, so as to avoid the circular relationship developed by Bryan (1977).

Using the social worlds framework, the study found that high specialization anglers have a higher resource dependency than low specialization anglers. Secondly, high specialization anglers placed greater importance on subscribing to a fishing magazine, watching fishing shows on television, and obtaining fishing information from state fish and wildlife brochures than low specialization anglers. Third, high specialization anglers saw many of the non activity-specific elements of fishing such as being close to the sea and getting away from the regular routine as being equal to or more important than activityspecific elements such as catching fish for eating as well as for the experience of the catch.

The importance of recognizing that recreational angling populations may contain diverse and distinct subpopulations has been well documented. Understanding that various subgroups of anglers may have different expectations, motivations and satisfactions has been shown to be a potentially vital component of any fisheries management plan (Hahn 1991, Fedler and Ditton 1994). The impetus is now on fishery 
managers to implement and utilize the recreational specialization framework (Ditton and Fedler 1989).

\section{RESEARCH OPPORTUNITIES}

Within the recreation/leisure literature, researchers have examined the motives people have to go recreational fishing, the importance these motives have on various sub-groups of anglers, and the concept of recreational specialization (Spaulding 1970; Bryan 1972; Moeller and Engelken 1972; Driver and Knopf 1976; Bryan 1977; Ditton 1977; Graefe 1981; Ditton and Fedler 1986; Loomis and Ditton 1987; Chipman and Helfrich 1988; Ditton et al. 1990; Hahn 1991; Ditton et al. 1992; Spencer and Spangler 1992; Spencer 1993; Fedler and Ditton 1994). Fedler and Ditton (1994) summarize that the research must be expanded in several crucial areas. A better understanding of the importance of certain motives to "market segments", such as anglers seeking unique experiences like offshore tuna fishing or fly fishing for sharks, so as to ensure their experiences and outcomes provide them maximum satisfaction. Further, they noted the value in deriving a better understanding of how angler satisfaction and motivations relate to their behavioral choices. Ideally, researchers should try to examine whether angler satisfaction changes if the mode by which they fish change, or the method by which they fish changes (fly fishing vs surfcasting, freshwater vs saltwater,.). Research should also be directed toward probing whether angler motives shift as angler specialization increases.

The recreational specialization framework developed by Bryan (1977) and reconceptualized by Ditton et al. (1992) is still a theory in need of testing and refining. Much empirical and conceptual work remains. The framework for testing the theory is in 
place and should be duplicated in any subsequent research. One of the research objectives is to find variable(s) which can be found to be consistent discriminators of recreational angler specialization.

This study contributes to the literature by providing a means by which marine recreational anglers level of recreational specialization may be easily and accurately measured. The study selects certain variables identified previously but not scientifically tested for significance. The study builds upon previous research and seeks to build upon these works in a small but hopefully significant way. Again, an ultimate goal of any recreational management policy is to provide the users with experiences which will provide them with satisfaction. The recreational specialization framework appears to be the best tool for this task. Being able to identify highly specialized anglers is a key component in this framework. 


\section{CHAPTER III}

\section{METHODOLOGY}

\section{RESEARCH HYPOTHESES}

The following research hypotheses were derived by segmenting groups of Rhode Island marine recreational fishermen based on their level of angling specialization.

Avidity, investment in angling, and fishing experience were tested separately as a means of classifying anglers based on their level of specialization.

H-1 Selected Rhode Island marine recreational anglers who report higher annual levels of fishing frequency will place greater importance on the sport and challenge motives marine recreational fishing compared to those individuals who fished less often.

H-2 Selected Rhode Island marine recreational anglers who report higher annual levels of fishing frequency will place less importance on the consumptive and harvest aspect of marine recreational fishing compared to those individuals who fished less often.

H-3 Selected Rhode Island marine recreational anglers who report the greatest monetary investment in angling will place more importance on the sport and challenge motive of marine recreational fishing compared to those individuals who have invested less money.

H-4 Selected Rhode Island marine recreational anglers who report the greatest monetary investment in angling will place less importance on the consumptive and harvest aspects of marine recreational fishing compared to those individuals who invested less money.

H-5 Selected Rhode Island marine recreational anglers who report the greatest number of years marine recreational fishing will place more importance on the sport and challenge motives of marine recreational fishing compared to those individuals who report fewer years marine recreational fishing. 
H-6 Selected Rhode Island marine recreational anglers who report the greatest number of years marine recreational fishing will place less importance on the consumptive and harvest aspects of marine recreational fishing than those individuals who report fewer years marine recreational fishing.

\section{Basis of the Hypotheses Within the Literature}

The three variables chosen as surrogates to testing the research hypothesis are: 1) avidity, 2) monetary investment in marine recreational fishing and 3) years of marine recreational fishing experience. The following discussion examines how the variables were utilized in previous research efforts.

\section{Avidity}

Avidity has been found to be a potentially valuable tool for discriminating different levels of angler specialization (Bryan 1977, 1979; Graefe 1981; Chipman and Helfrich 1988; Hahn 1991 and Ditton et al. 1992). Bryan (1977) used avidity as a component of his angler specialization concept which included skill level, equipment and setting preferences as a means to differentiate trout anglers. Graefe (1981) modified Bryan's specialization typology and adapted it to saltwater anglers using avidity as the core element of segmenting anglers. His study found that classifying anglers based on their level of participation was important for three reasons. First, classifying anglers based on their level of participation will result in a relatively distinct subgroup of fishermen. Second, this method utilized a fundamental measure of participation - annual fishing frequency. This is important because the method may be applicable to any other type of fishermen, from the general population to another more specialized group. Third, using participation as the 
means for segmenting anglers revealed separate and distinct catch-related motives for each sub-group. This was important because catch-related motives are the aspects of the fishing experience that are most likely to be influenced by allocation or regulation decisions. Chipman and Helfrich (1988) found experience level, measured in the frequency of fishing to be an important element in distinguishing varying levels of angler specialization. They noted that using concepts such as avidity, resource dependency, investment in angling and the importance of angling to one's lifestyle were factors important in developing a two dimensional framework from which the level of an anglers specialization may be measured.

Ditton et al. (1992) used annual fishing frequency as a means of segmenting marine recreational anglers into four uniform groups, each with similar participation levels. Their study found significant differences in the importance the four angler groups attached to non-activity specific (getting away from the regular routine, being close to the sea, relaxing), activity specific(catching fish for sport and pleasure, the experience of the catch), mediated interaction (reading fishing magazines, watching fishing shows, utilizing fishing information published in state fish and wildlife brochures) and resource dependent elements (catching a trophy fish, catching many fish, ect.).

\section{Monetary Investment}

Using the monetary investment of anglers is another indicator within Bryan's (1977) recreational specialization framework. Part of his recreational specialization typology related to the anglers use of equipment and resources. The more specialized angler desired more expensive and sophisticated equipment. Specific investment activities were 
more central to the more specialized angler, including the purchase of magazines on fishing, participation in tournaments, taking fishing vacations or purchasing a boat for fishing (Bryan 1977, Hahn 1991).

\section{Years of Fishing Experience}

The years of experience variable has not been tested within the literature, although it is commonly mentioned as a possible means to discriminate among different levels of angling specialization (Chipman and Helfrich 1988, Hahn 1991). This variable is a logical extension of the entire recreational specialization framework. The literature implies that the longer one participates in a recreational activity, the more specialized one may become.

\section{ASSUMPTIONS}

A-1 It is assumed that the fishermen participating in this study have an equal knowledge of the fishing system in which they interact.

A-2 It is assumed that the study population abides by the Rhode Island marine fishing regulations as set forth by the Department of Environmental management.

A-3 It is assumed that none of the anglers surveyed derive their primary income from the sale of the recreational fish they catch, therefore emphasizing the recreational pursuit of their fishing activity.

\section{STUDY POPULATION}

The study population for this research question comprised members of the Alliance of Rhode Island Sport Anglers (The Alliance). The Alliance is a diverse group of Rhode 
Island marine recreational anglers located throughout the state. For the purposes of this study, specific group affiliations were not pursued. Gigliotti and Peyton (1993) stated that recreational fishing club members are generally active and involve anglers who are interested in the management of the resource. Club members are usually an organized constituency who could be targeted and possibly recruited to enhance the adoption of certain management decisions (Ditton and Holland 1984). Recreational fishing club members also provide a source of data which is usually accessible through a single representative, allowing information to be passed along at group meetings or within club newsletters.

\section{DATA COLLECTION}

The data for this study was obtained through the use of a survey questionnaire. The questionnaire was part of a broader study conducted by the Rhode Island Department of Transportation Jamestown Bridge Artificial Reef Project. Surveys were distributed to the participating Alliance club presidents and were administered at club meetings. Completed

surveys were forwarded to Dr. William Gordon of the Department of Marine Affairs at the University of Rhode Island. The data were analyzed with the SPSS statistical package for personal computer application. Data were collected from late Fall of 1994 to early summer of 1995. A total of one hundred and thirty responses were analyzed.

\section{VALIDITY OF THE SURVEY INSTRUMENT}

The survey and questionnaire format used was based on the research of Dawson and Wilkins (1981), Graefe (1981), Ditton and Holland (1984), Fedler and Ditton (1986), 
Ditton et al. (1990), Ditton et al. (1992), Gigliotti and Peyton (1993), and Fedler and Ditton (1994). The motivation items used in the survey were single-item indicators consistent with the work of previous studies in this field. Driver and Cooksey (1977) concluded these motive items had acceptable reliability and validity. The angler responses to the motive statements were measured using a five point Likert scale which is universally accepted in the body of literature reviewed in this study. Fedler and Ditton (1994) emphasized the importance of using standard motive statements. Researchers who fail to build on previous work by using consistent wording and response formats with known reliability and validity parameters risk the ability to advance this body of literature which is firmly based on the utilization of previous research.

\section{THE SURVEY INSTRUMENT}

The study survey was titled the "RHODE ISLAND DEPARTMENT OF TRANSPORTATION 1994 RECREATIONAL ANGLER SURVEY". The survey was divided into three parts (see Appendix A). Part one contains three critical questions which supplied the data needed to segment the study populations into the specified sub-groups. Part one, Question 2 asked the angler how long they have been a marine recreational angler. The survey sought to identify the total number of times responding anglers participated in marine recreational fishing during the past year. Another question focused on the importance of economic impacts made by the angler by asking how much money they had spent on marine recreational fishing during the past year. Studies have shown that angler recall of fishing effort and expenditures are relatively accurate over a twelve month period (U. S. Department of Commerce 1993). Other questions pertained to the 
desired mode of fishing, noting whether respondents used a boat when they go fishing, and the utilization of artificial reefs.

Part two contained the motivation, harvest and consumption items as developed from the literature. These items were measured on a five-point Likert scale ranging from not at all to extremely important for the motivation items, and strongly disagree to strongly agree for the harvest and consumption items. Part two contained questions relating to the anglers targeted species of fish and the anglers reaction to various regulatory scenarios. Part two also contained questions about the respondents age, perceived skill level, equipment use, who and how many people they fish with, and tournament participation behavior.

Part three dealt with anglers perception regarding the adequacy of the management of Rhode Island marine recreational fisheries, boat facilities, and shoreline access. Questions regarding the anglers choice of regulatory restrictions and receptiveness to a saltwater fishing license were asked as well. There was also a section for the angler to make comments at the end. 


\section{CHAPTER IV}

\section{SURVEY RESULTS}

The total number of responses for the survey was 130 . The mean years of marine recreational fishing experience reported for the total study population was 28.35 (standard deviation of 13.91) (Table 1).

Table 1: Frequency Distribution of Respondent Years of Experience.

YEARS

$0-10$

$11-20$

$21-30$

$31-40$

$41-50$

$51+$

\section{FREQUENCY}

17

25

35

39

8

6

The mean age of study respondents was 48.47 years (standard deviation of 13.26).

Study anglers reported a mean of 52.04 for the number of times they engaged in marine recreational fishing (avidity) in the year prior to the survey (Table 2). These anglers reported an average of 22 times they went fishing from the shore, followed by an average of 20 times a year fishing from a private boat. 
Table 2: Frequency Distribution of Respondent Ages and Level of Avidity.

\section{AGE FREQUENCY AVIDITY FREQUENCY}

$\begin{array}{cccc}20-30 & 12 & 0-20 & 20 \\ 31-40 & 30 & 21-40 & 39 \\ 41-50 & 32 & 41-60 & 31 \\ 51-60 & 30 & 61-80 & 20 \\ 61-70 & 19 & 81-100 & 10 \\ 71+ & 7 & 101+ & 10\end{array}$

The anglers spent an average of $\$ 1,973$ per year on marine recreational fishing with a standard deviation of $\$ 4042$. This included indirect expenditures such as fuel, lodging and food, as well as bait, gear, and fees. Responding anglers reported they had an average economic impact on fishing related businesses of sixty three dollars per day they participated in marine recreational fishing. Forty percent reported they owned a boat from which they conducted their marine recreational fishing activities. The study population reported an average of eight spinning rod and reel combinations owned, as well as an average of one and one-half fly rods owned.

The anglers ranked striped bass as their most sought after species, followed by bluefish and summer flounder. Ninety two percent of the anglers reported they practiced catch and release methods of fishing. Eighty eight anglers reported they participated in a marine recreational fishing tournament. The most frequently mentioned tournaments 
included club sponsored tournaments, the Snug Harbor Striped Bass Tournament, the Rhode Island Striper Tournament and the Rhode Island Tuna Tournament.

In response to Question 15 which dealt with a reduction in the number of fish the angler may keep, eighty three percent responded that they would abide by the rules and regulations set forth by the Rhode Island Department of Environmental Management and would continue fishing at the same participation rate. Twelve percent reported they would fish for the same species of fish as well as other fish that were not affected by the limits. Three percent reported they would only fish for other species of fish that were not affected by the limits. Two percent reported they would stop fishing altogether.

In response to Question 16 which dealt with a catch and release requirement on all targeted species, seventy eight percent reported that they would abide by the rules and regulations set forth by the Rhode Island Department of Environmental Management and continue fishing the same amount for the same species of fish they previously did. Seventeen percent reported they would seek other species not affected by the regulations. Five percent reported that a catch and release requirement on all targeted species would cause them to stop fishing altogether.

\section{MOTIVE STATEMENT RESPONSES}

The mean responses to the motivational reasons for marine recreational fishing were as follows (the motives are grouped onto three categories): (1) harvest; (2) psychological and nature and (3) sport and challenge. The responses to part two, question twelve of the 
survey, which asks the angler to indicate how important each motive is to them as reasons for them to participate in marine recreational fishing, are listed in table three.

Table 3: Motive Statement Responses.

MOTIVE STATEMENT

\section{HARVEST}

To sell my catch

For consumption

To catch many fish

PSYCHOLOGICAL /

NATURE

For family recreation

Get away from regular routine

For relaxation

To be near the sea

To experience nature

To have fun

To be outdoors

SPORT/CHALLENGE

To catch a trophy fish

To develop fishing skills

The experience of the catch

For the challenge or sport
3.59

1.14

3.11

4.19

4.20

4.24

4.37

4.41

4.45

3.84

0.91

4.06
1.20

0.96

0.73

0.94

0.72

0.74

0.63
0.68

1.09

1.22

Consistent with previous research, this study found that the natural environment and psychological motives were all rated as very important to Rhode Island alliance anglers. In comparison with the other motives, these motives were all listed as the most important 
to the study population. Clearly, the study group placed great value on the aesthetic and escapist attributes that marine recreational fishing in Rhode Island provides.

Rhode Island club anglers rated the sport and challenge motives as very important reasons to participate in marine recreational fishing. They rated fishing for the challenge or the sport as most important while catching a trophy fish was important, but not as important as the other motives in the group.

Least important as a group and individually were the consumption and harvest motives. Selling of the catch, consuming the catch, and catching many fish all were rated as slightly to moderately important by the study group.

The mean responses to question 13 pertaining to angler satisfaction with consumption and harvest aspects of marine recreational fishing, were as follows in table 4.

Table 4: Mean responses indicating how strongly the angler agreed with each statement.

\section{SATISFACTION STATEMENT}

Bringing fish home to eat is an important part of fishing.

The bigger the fish, the better the trip.

The more fish I catch, the happier I am with my fishing trip.

A fishing trip can be successful even if no fish are caught.
MEAN

2.94

3.26

3.30

3.83

On the Likert scale utilized in this section, a value of one equaled strongly disagree, two equaled disagree, three equaled neutral, four equaled agree and five equaled strongly 
agree. The only question to which the study population came closest to agreeing with is question thirteen B, which asks the extent to which the angler agrees with the statement, "A fishing trip can be successful even if no fish are caught." These results would lead us to believe that while the catching of fish and the size of the fish caught is somewhat important, alliance anglers did not derive satisfaction from simply catching fish.

\section{COMPARISON WITH SIMILAR STUDIES}

Fedler and Ditton (1994) conducted a study examining seventeen comparable angler studies. Their goal was to understand the importance of various aspects of angling motivation at the sub-population level and within various contexts. Each study followed the same methodology pertaining to survey design and questionnaire format. Psychological, physiological, natural environment, social, fishery resource and skill and equipment motives were utilized from each study to create a broad chart of study responses. For purposes of their study, they took the mean responses of all the selected studies and created a grand mean for each motive category. Analysis of variance and ttests on the motivational scale resulted in significant differences among mean ratings (for an individual motivation item across studies or among items in the same study) when mean differences were .4 or greater (Fedler and Ditton 1994). Any individual study motive mean which falls .2 points above the grand mean is considered high $(\mathrm{H})$. Any individual study motive mean which falls .2 points below the grand mean is considered low $(\mathrm{L})$. This results in a difference of at least .4 in mean scores and indicates which motives were meaningfully different among groups (Fedler and Ditton 1994). For this analysis, the grand mean of Fedler and Ditton (1994) motives will be compared against the Rhode 
Island Alliance anglers responses (Table 5). The following is simply an illustrative comparison and not a rigorous analysis.

Table 5: Comparison with Fedler and Ditton (1994) studies. MOTIVE MEAN

GRAND MEAN

(H) (L) (-)

\section{PSYCHOLOGICAL}

Get away from routine

4.19

4.00

For relaxation

4.20

4.10

$\mathrm{H}$

FISHERY RESOURCE

For consumption

For the challenge or sport

For experience of the catch

To obtain a trophy fish

NATURE

To be outdoors

To experience nature

To be near the sea

SOCIAL

For family recreation

SKILL

To develop fishing skills

\subsection{1}

4.06

3.84

3.07

4.45

4.37

4.24

3.11

3.30

L

3.59

2.81

3.70

3.60

2.30

4.30

3.70

3.50

$\mathrm{H}$

$\mathrm{H}$

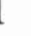


Fisher and Ditton's Texas shark angler study (in press) and closely resembled Ditton et al.'s (1988) shore-based black drum angler responses.

Rhode Island Alliance anglers rated fishery resource motives; for the challenge or sport of fishing, for the experience of the catch, and to obtain a trophy fish, as extremely important reasons why they participated in recreational fishing. Obtaining fish for eating was not as important to Rhode Island Alliance anglers as it was to anglers in other studies. Rhode Island Alliance anglers rated natural environment motives (to be outdoors, to experience natural surroundings, to be close to the sea) as more important than other angler groups. As with most populations of recreational anglers, Rhode Island Alliance anglers rated equally high the importance of physiological motives, such as getting away from the daily routine and for relaxation. Development of skills was rated higher by Rhode Island Alliance anglers than most angling populations. Interestingly, Rhode Island alliance anglers rated the social component of family recreation as low in importance compared to other angling populations. This seems to be consistent with other studies of specialized groups such as the Texas shark angler study (in press) and the shore-based black drum angler study (Ditton et al. 1988). These anglers may chose to participate only with other anglers as specialized and dedicated as themselves.

\section{COMPARISON WITH OTHER FISHING CLUBS}

The only other study in the literature which used fishing club members as the source for their data was conducted by Ditton and Holland (1984). This study examined Texas Gulf Coast Conservation Association members in the Houston-Galveston area. The Gulf Coast members reported they participated in recreational fishing a mean of 37 days per 
year. Alliance members reported a mean number of days fishing in one year to be 52 .

Gulf Coast members reported a mean age of 54 years, compared with 48 years old for Alliance anglers. The responses to the motivational statements by the two groups were tabulated in Table 6:

Table 6: Alliance and Gulf Coast mean response comparison.

MOTIVE

ALLIANCE MEAN

GULF COAST MEAN

\section{PSYCHOLOGICAL}

Get away from routine

4.19

3.90

For relaxation

4.20

4.20

\section{FISHERY RESOURCE}

For consumption

For the challenge or sport

For experience of the catch

To obtain a trophy fish

\section{NATURE}

To be outdoors

To experience nature

To be near the sea

SOCIAL

For family recreation

\section{SKILL}

To develop fishing skills

The following discussion is simply an observation by the author and is not intended as a finding of this thesis. Five motive items stand out as markedly different. The first three 
motive items; For the challenge or the sport, For the experience of the catch and To obtain a trophy fish, fall into the fishery resource category. Alliance anglers revealed a substantially higher dependency on the resource than Gulf Coast anglers. Based on the literature, Alliance members may constitute a more specialized social world than the Gulf Coast anglers. Alliance anglers meet one of the main criteria for a more specialized social world in that they reported a greater frequency in the levels of participation than Gulf Coast anglers. In the nature category, Alliance anglers rated to be near the sea almost a full point higher. Alliance anglers rated developing their fishing skills as important while Gulf Coast anglers rated it as less important. The enhancement and continued refinement of ones skills is another potential indicator of being more specialized.

The findings of this comparison are illustrative of the importance of not assuming subgroups that appear similar will have similar motivations, perceptions, and satisfactions with their recreational fishing experiences. Fishery managers should understand the constituency they manage and tailor appropriate regulations and experiences to them based on their revealed expectations and satisfactions.

Responses to three similar questions dealing with angler orientation towards the catch showed striking similarity. In response to the statements; The bigger the fish, the better the trip; The more fish I catch, the happier I am with my fishing trip and, A fishing trip can be successful even if no fish are caught, both groups gave a mean response of 3.2, 3.3 and 3.8 respectively. All of which were slightly higher than neutral in agreement. The same observations which were cited earlier regarding these statements can be applied here. 
While it is not critical to the satisfaction of anglers, it seemed the catching of fish was still an important factor in overall angler satisfaction.

\section{SURVEY DIFFICULTIES}

It must be mentioned that the response rate for this study was not able to be accurately calculated. The Alliance club presidents were given the surveys to be passed out at their club meetings. Unfortunately, they were very secretive about their membership sizes and did not reveal their overall membership numbers. It seems that the Alliance club presidents and some of their members were not convinced of the utility of this study and the accompanying artificial reef project survey. It is hoped that with further contact and involvement with the Alliance clubs and its members that their trust can be gained.

From estimating what is known about the potential size of the Alliance membership and the expected turn out at their meetings that the sample universe would approximate 1500. This results in a response rate of nine percent. One reason for such a low response rate was the length of the survey. Since the survey contained questions from two distinct studies, there was a substantial amount of data sought. In speaking with some club members, they stated that the survey took too long to fill out. It must be noted that the limited time frame in which to administer the surveys and the lack of any previous attempt to solicit data from the Alliance groups necesitated a comprehensive survey. Any future surveys of the study group should be more direct and limited in scope. 


\section{CHAPTER V}

\section{TESTING OF THE HYPOTHESES}

The literature revealed various ways by which angler specialization can be measured. The study utilizes the methods suggested by Chipman and Helfrich (1988), Graefe (1981), Ditton et al. (1992), and Hahn (1993). These authors believed that only a small number of specialization variables may be fundamental determinants of angler specialization. These determinants are (1) fishing frequency, (2) investment in recreational fishing, and (3) years of fishing experience.

The first step in testing the hypotheses was to state the null hypotheses. To summarize for all the hypotheses, the null hypotheses stated that Rhode Island marine recreational anglers who reported higher levels of the three specified variables would not place significantly different levels of importance on the sport, challenge, consumptive, and harvest aspects of marine recreational fishing than those individuals who report lower levels of the three specified variables. The hypotheses were tested as a one-tailed test at a confidence interval of $90 \%$. It should be noted that many social science researchers utilize a confidence level of $95 \%$ which will allow for a greater degree of accuracy in supporting or rejecting the hypotheses. However, a 95\% confidence interval was deemed too restrictive for this study. Previous researchers (Jones 1984) have approved of the $90 \%$ confidence interval in social science research.

The means and the standard deviations for three variables will then be calculated. All respondents who fall greater than one standard deviation above the mean will be classified 
as highly specialized anglers. Anglers who report equal to or less than one standard deviation above the mean will be classified as less specialized. The rationale behind using the standard deviation as a means of classifying the anglers is twofold. First, it is a measurement that is easy to obtain. Second, it had never been used in the literature in this manner and was seen as a unique approach to the research. The mean responses of the highly specialized group to selected motive items will then be compared to the mean responses of the less specialized respondents by using a two sample difference of means $t$ test. The difference of means $t$-test is a statistical test which compares the means of two independently random samples. The samples must be selected independently of each other, which means the selection of an observation from sample one will have no bearing on the selection of an observation from sample two. If the overall sample is random, and one is comparing two sub-samples from the larger sample, the assumption of independence between samples will automatically be met since all cases in the total sample will have been selected independently of each other (Blalock 1979). The parameters for the test were as follows: (1) The data set represented a random selection of Rhode Island Alliance anglers; (2) The student's $t$ distribution was used to determine significance; (3) the confidence level was ninety percent (.10); (4) The test was a one-tailed test for direction, and (5) The test statistic (t) was computed using the following equation:

$$
T=\frac{X_{1}-X_{2}}{\sqrt{\frac{\left(N_{1}-1\right) s d_{1}^{2}+\left(N_{2}-1\right) s d_{2}^{2}}{N_{1}+N_{2}-2}} * \sqrt{\frac{N_{1}+N_{2}}{N_{1} N_{2}}}}
$$

where: $X_{1}=$ the mean of sub-population one

$$
\mathrm{X}_{2}=\text { the mean of sub-population two }
$$


$\mathrm{N}_{1}=$ the number of observations in sub-population one

$\mathrm{N}_{2}=$ the number of observations in sub-population two

$\operatorname{sd}_{1 \&} \mathrm{sd}_{2}=$ the standard deviation of sub-population one and two

The degrees of freedom for the table statistic is equal to $\mathrm{N}_{1}+\mathrm{N}_{2}-2$. Since we have a study population $\mathrm{N}$ of 130 , the degrees of freedom will always be 128 . The closest degrees of freedom found on the $t$ distribution table is 120 (Blalock 1979). The corresponding levels of significance at 120 degrees of freedom is tabulated in table seven.

Table 7: Levels of significance for a one-tailed test at $\mathrm{df}=120$.

df Level of significance of one-tailed test .10 .05 .025 120 1.289 1.658 1.980

The motive responses were condensed into two groups for hypotheses testing purposes. Group one consisted of consumption and harvest motive statements. Group two consisted of the sport and challenge motive statements. In each group, the highly specialized anglers response means were compared with the less specialized anglers response means using the formula and parameters outlined above. In order to support or reject the hypotheses, the $t$ statistic for each motive statement was compared to the appropriate table statistic derived from the student $t$ distribution outlined in Table 7. Since the study was testing for direction, that is, it was believed that certain mean responses from one sub-population are either significantly greater than or significantly less than the other sub-population mean responses, a one tailed test was utilized. The table statistic for 
a one tailed test of direction at a confidence level of ninety percent is 1.289 . If our test statistic is greater than this table statistic, we can say with ninety percent confidence that the difference between the two sample means are statistically different. When this holds true, the null hypothesis is rejected thereby accepting the research hypothesis.

\section{EXAMINING THE VARIABLE AVIDITY}

The first variable tested was the respondents annual level of fishing frequency or AVIDITY. The number assigned to a respondents level of avidity was the sum of question eight in part one of the survey. Part I, Question 8 from the survey asked the angler to recount the number of times they went saltwater fishing during the previous year. The respondent had five categories to respond to. The categories were: (1) number of times from their own boat; (2) number of times from another private boat; (3) number of times from a charter boat; (4) number of times on a party boat and (5) number of times from shore.

Restatement of hypotheses one and two:

H-1 Selected Rhode Island marine recreational anglers who report higher annual levels of fishing frequency will place greater importance on the sport and challenge motives of marine recreational fishing compared to those individuals who fished less often.

H-2 Selected Rhode Island marine recreational anglers who report higher annual levels of fishing frequency will place less importance on the consumptive and harvest aspects of marine recreational fishing compared to those individuals who fished less often.

Testing of the first two hypotheses first required computing the mean and standard deviation of the variable AVIDITY. The results were a mean of 52.04, a standard 
deviation of 37.02 , and a skewness level of 1.272 which indicated a slightly positive skewed data set. Highly specialized anglers were considered those who reported levels of Avidity greater than one standard deviation from the mean (AVIDITY $>1$ SD), which would was 89.06 . This number was rounded off to 89 . The two sub population means were then tested using a two-sample student $t$-test. The number of valid observations was 126 (96.9 percent). The number of observations for AVIDITY $>1$ SD was 16 . Thus, $\mathrm{N}_{1}$ $=16$. The number of observations for AVIDITY $\leq 1 \mathrm{SD}$ was 110 . Accordingly, $\mathrm{N}_{2}=$ 110. The analysis of the two sub-groups and their test statistic are as follows in table 8 .

Table 8: Testing the variable AVIDITY (a "*" denotes a significant result).

MOTIVE STATEMENTS AVIDITY $>1$ SD SPORT / CHALLENGE

To catch a trophy fish

To develop fishing skills

The experience of the catch

For the challenge or sport

A fishing trip can be successful even if no fish are caught.

\section{HARVEST}

To sell my catch

For Consumption

To catch many fish

The bigger the fish, the better the trip

Bringing fish home to eat is an important part of fishing

$3.57 \quad 0.46$

3.94

4.19

1.24

0.75

4.46

0.63

4.06

1.00

1.17

1.00

2.57

1.10

2.01

1.16

2.90

1.01

2.96

1.20

MEAN SD

AVIDITY $\leq 1 \mathrm{SD}$ MEAN

SD

$$
3.00
$$

0.35

1.12

0.59

3.79

4.01

0.88

3.74

1.05 $t$ statistic

$t$ statistic

*5.8340

* 1.3171

$* 2.4400$

*1.9700

.1400 
Table 8 continued:

$\begin{array}{llllll}\text { The more fish I catch, the } & 3.25 & 1.34 & 3.27 & 1.19 & 0.0618\end{array}$ happier I am with my fishing trip.

\section{Results of Testing the Variable AVIDITY}

In the first group of motive statements under the SPORT / CHALLENGE category we find that highly specialized anglers rated all the motive statements as significantly more important than less specialized anglers except for two. The statements, "To catch a trophy fish" and "The experience of the catch", received extremely higher mean responses by highly specialized anglers than less specialized anglers. It would seem that these anglers enjoy the "hunt" and the skill involved in pursuing and landing a large specimen. The desire to catch a trophy fish may give these anglers status among their peers as successful and skillful anglers, which may be what they want to be seen as. Catching a trophy fish may provide the angler with proof that the commitment to the sport they have made has paid off.

The motive statement, "To develop fishing skills", was not rated as significantly different by the highly specialized group, although both groups rated the motive as between moderately and very important. A possible reason for the lack of a significant difference in this motive may be that highly specialized anglers feel they are already highly skilled anglers, and any further practice is simply fine tuning these skills. The motive statement, "A fishing trip can be successful even if no fish are caught", was not rated as significantly more important by the highly specialized group. Importantly, both groups rated this motive as relatively high in importance. 
In the second group of motive statements under the HARVEST category we find that highly specialized anglers rated the motive statements: To catch many fish and ; The bigger the fish, the better the trip, as significantly less important for reasons why they go marine recreational fishing than less specialized anglers. This supports a number of writer's conclusions that more specialized anglers are less concerned with the quantitative aspects of the catch than their less specialized counterparts. There was no significant difference between the two groups for the motive statements: To sell my catch; For consumption; and, Bringing fish home to eat is an important part of fishing. The reason for these results may be simply that the selling and consuming of the catch are not important motives to most Alliance anglers as reflected by no response means greater than three (neutral) by either sub group. Regarding the motive statement; The more fish I catch, the happier I am with my fishing trip, there was not found to be any significant difference between the two groups. However, both groups reported slightly higher than neutral mean responses which indicates that that Alliance anglers attach some importance to the catching of fish. This result is supported by previous research and should not detract from the other findings. Researchers have stated that while the catching of fish is important, it is relatively less important then other facets of the anglers experience.

From the findings of the use of the variable AVIDITY as a tool to discriminate anglers by their level of recreational specialization, $\mathbf{H}-\mathbf{1}$ and $\mathbf{H}-2$ are supported at the .10 confidence level. It appears that the use of AVIDITY facilitates a stronger and more convincing means of revealing differences among the sport and challenge motive statements than the harvest and consumption statements. 


\section{General Results of the AVIDITY Variable}

Highly specialized anglers in the AVIDITY category revealed they felt as skilled or more skilled than their peers. Fifty percent of the highly specialized anglers in the AVIDITY category reported they caught the same amount of fish as other anglers. The other fifty percent reported that they caught more fish than other anglers. The same percentages apply when highly specialized anglers were asked their perceived skill level. Fifty percent reported they were more skilled than other fishermen and fifty percent reported they were equally skilled. Twenty six percent of less specialized anglers reported they caught more fish than other anglers. Fifty four percent reported they caught the same amount and twenty percent reported they catch less than other anglers. Twenty five percent of less specialized anglers reported they were more skilled than other anglers, while sixty percent reported they were equally skilled and fifteen percent reported they were less skilled than other anglers.

Both sub-groups reported striped bass as their most sought after recreational species, followed by bluefish. Highly specialized anglers reported summer flounder as their third most sought after species while less specialized anglers reported blackfish as their third most sought after species.

\section{EXAMINING THE VARIABLE INVEST}

Testing of the third and fourth hypotheses which related to an anglers monetary investment in angling first required condensing angler responses to Part I, Question 16 into a single figure. Question 16 asked the angler to approximate the amount of money 
(s)he spent in the past year on seven categories. These categories were: (1) Fishing gear; (2) Bait; (3) Fuel; (4) Docking/ramp fees; (5) Lodging; (6) Charter/Party boat fees and (7) Food. After summing the angler responses to these seven categories, the variable INVEST was created. The mean and standard deviation of the variable INVEST was subsequently computed. The INVEST variable had 112 valid observations. The results were a mean of 1973.36 dollars with a standard deviation of 4042.46 dollars. Statistically, it is expected that the standard deviation should be less than or close to the mean in a normally distributed population. A skewness test indicated an amount of 5.290, which indicated an extremely skewed distribution. Upon further exploration of the data, it was found that three respondents reported unusually high levels of expenditures relative to the rest of the population. A box plot was created which is useful in indicating extreme values in a distribution. The box plot revealed three extreme values of $\$ 31,000, \$ 25,000$, and $\$ 11,800$. These respondents revealed high expenditures in fishing boat related areas such as dock fees and fuel. This may indicate that these respondents operated their boats as charter boats, or were involved in an extremely capital intensive method of fishing. It was determined that these observations would be excluded from the analysis of the INVEST variable. Recalculating the INVEST variable created a mean of 1405.65 and a standard deviation of 1692.70. A test of the populations skewness indicated a level of 1.997 , or moderately skewed. The resulting population had 109 valid observations (84\%). These results were determined to be acceptable for testing.

Highly specialized anglers were considered those individuals who reported levels of INVEST greater than one standard deviation from the mean (INVEST > 1SD), which 
would be 3098.35. This number was rounded off to 3098. INVEST $>1$ SD had an N equal to $12\left(N_{1}=12\right)$. INVEST $\leq 1 \mathrm{SD}$ had an $\mathrm{N}$ equal to $96\left(\mathrm{~N}_{2}=96\right)$. The two sub population means were then tested using a two-sample student $t$-test.

Restatement of Hypotheses three and four:

H-3 Selected Rhode Island marine recreational anglers who report the greatest monetary investment in angling will place more importance on the sport and challenge motives of marine recreational fishing compared to those individuals who have invested less money.

H-4 Selected Rhode Island marine recreational anglers who report the greatest monetary investment in angling will place less importance on the consumptive and harvest aspects of marine recreational fishing compared to those individuals who invested less money.

The results of the means and standard deviations of the two sub-groups and the test statistic are as follows in table 9 :

Table 9: Testing the variable INVEST (a "*" denotes a significant result).

MOTIVE STATEMENTS

SPORT / CHALLENGE

To catch a trophy fish

To develop fishing skills

The experience of the catch

For the challenge or sport

A fishing trip can be successful even if no fish are caught.
INVEST $>1 \mathrm{SD}$

MEAN

SD

3.46

1.05

3.54

4.23

4.23

3.62

1.05

1.17

0.73

0.77 $t$ statistic

MEAN

SD

1.41

1.10

0.93

0.88

4.17

3.71

1.06
0.2843

$\boldsymbol{t}$ statistic

0.4980

0.1491

0.5456

0.2264 
Table 9 continued:

\begin{tabular}{|c|c|c|c|c|c|}
\hline HARVEST & MEAN & SD & MEAN & SD & $t$ statistic \\
\hline To sell my catch & 1.08 & 0.28 & 1.23 & 0.75 & 0.6844 \\
\hline For Consumption & 2.85 & 1.07 & 2.49 & 1.04 & 1.1271 \\
\hline To catch many fish & 1.42 & 0.51 & 1.96 & 0.67 & *2.6916 \\
\hline $\begin{array}{l}\text { The bigger the fish, the } \\
\text { better the trip }\end{array}$ & 3.23 & 1.30 & 3.21 & 1.18 & 0.0547 \\
\hline $\begin{array}{l}\text { Bringing fish home to eat is } \\
\text { an important part of fishing }\end{array}$ & 3.00 & 1.00 & 2.85 & 1.18 & 0.4214 \\
\hline $\begin{array}{l}\text { The more fish I catch, the } \\
\text { happier I am with my } \\
\text { fishing trip. }\end{array}$ & 3.27 & 1.55 & 3.34 & 1.20 & 0.1715 \\
\hline
\end{tabular}

Results of Testing the Variable INVEST

No significant differences were found in any of the motive statements between the two sub-groups except in one instance. Anglers in the highly specialized INVEST sub-group rated, To catch many fish, as significantly less important to their overall satisfaction with their marine recreational fishing experience than anglers in the less specialized INVEST sub-group.

General Analysis of the INVEST Variable

Eighty percent of the highly specialized anglers in the INVEST category reported they believed they caught more fish than other anglers. No anglers in this group reported they believed they caught less fish than other anglers. Seventy percent reported they were 
more skilled than other anglers while the remaining anglers reported they were equally as skilled.

The highly specialized INVEST anglers reported striped bass and tuna as their most targeted species. The second most sought after species of fish was cod. Less specialized INVEST anglers reported striped bass and bluefish as their most sought after species of fish.

\section{EXAMINING THE VARIABLE YEARS}

Hypotheses five and six were tested using the variable YEARS. YEARS was calculated by simply recording the angler response to Question 2 in part one. Question 2 asked how long the angler has been a marine recreational angler. The mean and standard deviation of the variable YEARS was subsequently computed. The results were a mean of 28.35 years experience with a standard deviation of 13.91 years experience. A test for skewness $(.220)$ revealed a slightly skewed distribution. The YEARS distribution had 125 observations (96.1 percent). Highly specialized anglers were considered those respondents who reported levels of YEARS greater than one standard deviation from the mean, which would be 42.26 . This number was rounded off to 42 years. YEARS $>1$ SD was equal to $14\left(\mathrm{~N}_{1}=14\right)$. YEARS $\leq 1 \mathrm{SD}$ was equal to $111\left(\mathrm{~N}_{2}=111\right)$. The two sub population means were then tested using a two-sample student $t$-test.

Restatement of Hypotheses five and six:

H-5 Selected Rhode Island marine recreational anglers who report the greatest number of years marine recreational fishing will place more importance on the sport and challenge motives of marine recreational fishing compared to those individuals who report fewer years marine recreational fishing. 
H-6 Selected Rhode Island marine recreational anglers who report the greatest number of years marine recreational fishing will place less importance on the consumptive and harvest aspects of marine recreational fishing than those individuals who report fewer years marine recreational fishing.

The results of the means and standard deviations of the two sub-groups and the test statistic are as follows in table 10:

Table 10: The testing the variable YEARS (a "*" denotes a significant result.)

MOTIVE STATEMENTS $\quad$ YEARS $>1 \mathrm{SD} \quad$ YEARS $\leq 1 \mathrm{SD} \quad t$ statistic

SPORT / CHALLENGE

MEAN SD

MEAN SD $t$ statistic

To catch a trophy fish

$4.10 \quad 1.36$

3.10

1.42

*2. 4944

To develop fishing skills

$3.81 \quad 1.01$

3.56

1.28

0.7028

The experience of the catch

$4.55 \quad 0.81$

4.00

1.25

*1.6012

For the challenge or sport

4.58

1.27

3.82

0.78

*3. 1706

A fishing trip can be

3.93

0.92

3.83

0.97

0.3655

successful even if no fish

are caught.

\section{HARVEST}

To sell my catch

$100=0.00$

1.24

0.73

1.2257

For Consumption

2.57

1.28

2.59

1.06

0.0649

To catch many fish

2.01

1.27

2.98

1.19

$* 2.8580$

The bigger the fish, the

3.02

1.38

3.29

1.13

0.8214

better the trip

Bringing fish home to eat is

2.90

1.29

2.95

1.22

0.1436

an important part of fishing

The more fish I catch, the

3.14

1.17

3.30

1.22

0.4644

happier I am with my

fishing trip. 


\section{Results of Testing the Variable YEARS}

In the sport and challenge category, the motive statements; "To catch a trophy fish", "The experience of the catch" and "For the challenge or sport" all were rated as significantly more important by the highly specialized YEARS group than the less specialized YEARS group. As with the pattern that has evolved from the first two variables, these sporting attributes become more important as the level of specialization increases.

Two motive statements, "To develop fishing skills" and "A fishing trip can be successful even if no fish are caught", did not invoke a higher level of importance by the highly specialized YEARS group. As discussed earlier, at a high level of specialization, an angler may feel their skills are fully developed. It appears that anglers above a certain level of specialization (probably above a very low level of specialization) all uniformly agree that a fishing trip can be successful even if no fish are caught.

In the harvest section, highly specialized YEARS anglers only rated "To catch many fish" as significantly more important than less specialized YEARS anglers. One might expect that after many years of fishing, simply catching many fish is no longer relevant to highly specialized YEARS anglers as opposed to catching a trophy fish. While the other motive statements in this section did not reveal any differences in terms of importance, they all had lower mean values assigned to the highly specialized YEARS anglers than those assigned to the less specialized YEARS anglers. Upon review of the findings of the 
examination of the YEARS variable, H-5 was strongly supported and H-6 was tentatively supported.

\section{General Analysis of YEARS Variable}

Thirty five percent of highly specialized members of YEARS reported they caught more fish than other anglers while fifty percent reported they caught the same amount of fish as other anglers. These anglers reported that Striped bass were their most sought after species of fish followed by bluefish. Forty three percent of highly specialized YEARS anglers reported they felt they were more skilled than other anglers while fifty seven percent reported they were equally skilled.

Twenty nine percent of less specialized members of YEARS reported they caught more fish than other anglers while fifty four percent reported they caught the same amount as other anglers. Seventeen percent said they caught less than other anglers. Striped bass was again mentioned as the most sought after species of fish followed by bluefish and blackfish. Less specialized anglers in YEARS reported thirty nine percent of the time that they believed they were more skilled than other anglers while fifty percent said they were felt equally skilled. Eleven percent reported they believed they were less skilled than other anglers. 


\section{SUMMARY OF THE RESULTS}

Reviewing the testing of the Hypotheses, it was concluded that $\mathbf{H}-\mathbf{1}$ and $\mathbf{H}-\mathbf{2}$ were supported. The variable AVIDITY proved to be a useful discriminator of statistically different levels of angler specialization. It proved most powerful in revealing significant differences in the Sport and Challenge motive statements.

Disappointingly, $\mathbf{H}-\mathbf{3}$ and $\mathbf{H}-\mathbf{4}$ were rejected. It must be noted that the reason for the lack of support for the INVEST hypotheses may be from a poor survey design of the question. The INVEST variable elicited the lowest response rate. Respondents were required to answer several questions which were combined to form the variable INVEST. It also required further manipulation to lend itself to statistical testing as proposed in the methodology section of this study. It simply may be that the use of monetary investment as a means of discriminating anglers is not a viable method. Further study must be done to determine if the monetary expenditures an angler makes are directly proportional to his/her income. If this is the case, the use of the variable INVEST as utilized in this study would be inappropriate.

After testing the variable YEARS, H-5 and H-6 were supported. As with the variable AVIDITY, YEARS proved more powerful in supporting the hypothesis relating to the sport and challenge motives for recreational fishing than the harvest and consumption motives. 


\section{Significance of the Results}

Based on the results of this study, several conclusions can be drawn. Intuitively, one would assume that by nature members of fishing clubs would all be highly specialized and therefore indistinguishable from each other in terms of motivations sought and overall fishing satisfactions. As was revealed in the comparisons with the other studies (Fedler and Ditton, 1994), Alliance anglers were in fact more specialized than their counterparts. However, the methodology utilized in this study showed that even at a relatively high level of specialization, sub-groups can be formed with distinct characteristics. This reinforces previous research conclusions that it is important not to view angling populations as homogeneous! Each angling population must be evaluated and managed based on the characteristics they reveal. These characteristics can only be properly identified through applying the recreational specialization framework expanded upon in this study.

Second, some variables proved more useful as tools to discriminate anglers by their level of specialization than others. The variable AVIDITY appeared to be the best tool for overall use for both the sport and challenge category and harvest and consumption category. The variable YEARS provided expected results, but with minimal decisiveness in the harvest and consumption category. The variable INVEST failed to contribute to this study in a meaningful way.

Third, from the standpoint of a fisheries manager, one could argue that this study has shown that highly specialized anglers members may be willing to accept future restrictive regulations if they have ample and diverse opportunities to go fishing. It would seem plausible that these anglers would rather catch a large trophy fish than many small 
specimens. Therefore, highly specialized anglers may be more receptive to regulations that reduces their creel limit and increases their minimum size limit while still allowing them to catch and keep a large trophy fish. 


\section{MANAGEMENT IMPLICATIONS}

This study illustrates the need for fisheries managers and even state tourism and economic development officials to create a detailed data base of the recreational anglers in their state. It is not likely, due to budgetary constraints, that the federal government will conduct any broad survey of the type utilized in this study in the near future. Therefore, it is up to the states to gather this crucial social data on recreational anglers. It is also unlikely that the ASMFC will utilize this social data when allocating harvest quotas between commercial and recreational anglers. Naji Lazar of the ASMFC stated that although social data of the type gathered in this study would be extremely useful to ASMFC managers, it is not possible to efficiently gather this data. The methodology, while ideal for fisheries management, is not practical for the type of management structure that presently exists.

The onus will be on the states to allocate monies from the Wallop-Breaux Trust Fund and any local funds towards programs which will best suit its constituents. The only means by which this can be accomplished is by understanding the motivations, expectations, desires, and satisfactions of the marine recreational anglers in their jurisdiction. The recreational specialization framework utilized in this study would provide the means towards better understanding these characteristics. The feedback and cooperation of the states recreational fishing clubs would be a vital step creating a state plan of soliciting and compiling social data on recreational anglers. Rhode Island House Representative Eileen Naughton of Warwick, Rhode Island believes that the state needs to form a better working relationship with its recreational fishing clubs. She feels that only 
with the cooperation and support of local recreational fishing clubs can fishery management programs such as fish aquaculture development and artificial reef creation be successful.

\section{CONCLUSION}

Angler specialization may be the key determinant of an anglers satisfaction with his or her recreational fishing experience. The real challenge for fisheries managers is to be able to utilize the specialization concept in allocating resources. Many questions arise which are critical to the future success of any recreational fisheries management plan. For example, should some angler groups receive preference over others? If certain anglers desire solitude and fishing in isolated areas, then management regulations which restrict access and the number of anglers in an area or fishery may be appealing and desirable to them. Fishing under these conditions would probably yield the greatest satisfaction among this group, but what about the anglers excluded from the area? These questions can only be addressed if managers know what the social characteristics of the various sub-groups of anglers they manage are.

The ideal methodology which can be utilized by state fishery managers is to compare club fishermen to the general population of anglers in the state. Differences between the two groups should be probed and studied. Do anglers at the same levels of avidity in each group exhibit similar motive statement responses? Other variations of this methodology could include comparisons between different modes of fishing or species sought. An important problem which must be addressed with this type of study is that it is often difficult or impossible to get an accurate sample, since most anglers fish by multiple modes 
and for several species of fish. An interesting proposition would be to test whether an angler's motivations shift as they change mode or species sought. Further, does an anglers motivational preferences change as their level of specialization changes over time?

Utilizing the methodology used in this study may help state economic development and tourism department better understand the importance of recognizing the diversity of the recreational angling public. These managers should devise programs to market the different types of fishing opportunities available in their state. They must recognize that private boat anglers may have different expectations and satisfactions than that of charter and party boat anglers. Just as important, the findings of this study can help show how funding programs such as artificial reefs and fishery aquaculture can be profitable for the state. By increasing and diversifying recreational angling opportunities, a greater number of anglers will be satisfied with their recreational fishing experiences- which is the desired goal of any recreational fisheries management! 
APPENDIX A

\section{RHODE ISLAND DEPARTMENT OF TRANSPORTATION 1994 RECREATIONAL ANGLER SURVEY}

The Rhode Island Department of Transportation (RIDOT) is currently investigating the use of the Old Jamestown Bridge for construction of a series of artificial reefs. One of the goals of this project would be to enhance fishery habitat. Designed jointly by the Alliance of Rhode Island Saltwater Fishing Clubs and RIDOT, this survey seeks information on your near and offshore fishing activities. Your participation and input into this process is much appreciated. Thank you!

Only survey questions that pertained to this thesis are listed below.

\section{** Part 1 **}

2) How long have you been a marine recreational angler?

8) How many times did you go marine recreational fishing last year?

From your own boat

From another private boat

On a charter boat

On a party boat

From the shore

15) Which marine fishes do you target in the following areas:

Narragansett Bay

Nearshore (0-3 miles)

Inshore (3-10 miles)

Offshore $(11+$ miles $)$ 
16) To demonstrate the economic impact of recreational fishing, approximately how much money did you spend in Rhode Island last year while marine recreational fishing:

Fishing gear \$ Bait \$ Fuel \$

Docking/ramp fees \$ Lodging \$

Charter/party boat fees $\$$ Food \$

17) To demonstrate the economic impact of recreational fishing, how much money do you spend on an average day of marine recreational fishing?

$\$$

\section{** Part II **}

1) What is your age?

6) How many saltwater fly fishing rods do you own?

7) How many conventional saltwater fishing rods do you own?

8) Have you ever participated in a saltwater fishing tournament? Please Circle

(yes) (no)

8a) If yes, which tournaments?

9) Approximately what percentage of your marine recreational fishing time is spent on each of the following?

Saltwater flyfishing

Saltwater rod and reel fishing

Other (please explain) 
10) Do you feel you catch (MORE, SAME, LESS) fish than other marine recreational fishermen?

11) Do you feel you are (MORE, SAME, LESS) skilled than other marine recreational fishermen?

12) Below is a list or reasons why people go marine recreational fishing. Please indicate how important each item is to you in terms of your marine recreational fishing experience. Please use the following scale.

$$
\begin{aligned}
& \text { NOT }=\quad \text { not important at all } \\
& \text { SLIGHT }=\text { slightly important } \\
& \text { MODERATE = moderately important } \\
& \text { VERY }=\quad \text { very important } \\
& \text { EXTREME }=\text { extremely important }
\end{aligned}
$$

\section{REASONS:}

For relaxation NOT SLIGHT MODERATE VERY EXTREME

For consumption NOT SLIGHT MODERATE VERY EXTREME

For challenge or sport ..... NOT SLIGHT MODERATE VERY EXTREME To develop fishing skills ... NOT SLIGHT MODERATE VERY EXTREME To catch a trophy fish ...... NOT SLIGHT MODERATE VERY EXTREME To be outdoors NOT SLIGHT MODERATE VERY EXTREME

To experience natural surroundings NOT SLIGHT MODERATE VERY EXTREME

For the experience of the catch NOT SLIGHT MODERATE VERY EXTREME To get away from the regular routine NOT SLIGHT MODERATE VERY EXTREME

To be with friends NOT SLIGHT MODERATE VERY EXTREME

To be near the sea NOT SLIGHT MODERATE VERY EXTREME To catch many fish NOT SLIGHT MODERATE VERY EXTREME 
For family recreation ....... NOT SLIGHT MODERATE VERY EXTREME

To have fun NOT SLIGHT MODERATE VERY EXTREME

To sell my catch NOT SLIGHT MODERATE VERY EXTREME

13) Please indicate the extent to which you agree or disagree with each of the following? Please Circle

A. The more fish I catch, the happier I am with my fishing trip.

Strongly Disagree / Disagree / Neutral / Agree / Strongly Agree

B. A fishing trip can be successful even if no fish are caught?

Strongly Disagree / Disagree / Neutral / Agree / Strongly Agree

C. The bigger the fish, the better the trip.

Strongly Disagree / Disagree / Neutral / Agree / Strongly Agree

D. Bringing fish home to eat is an important part of fishing.

Strongly Disagree / Disagree / Neutral / Agree / Strongly Agree

14) What is the most important marine recreational saltwater species you

fish for in Rhode Island?

Second most important?

Third most important?

15) If the Rhode Island Department of Environmental Management (DEM) determined it was necessary to REDUCE the number of fish you may keep from the species you listed above, would you: PLEASE CHECK ONE OF THE FOLLOWING

Continue to fish the same amount you always have...

Fish for other species

Stop marine recreational fishing all together 
16) If the Rhode Island DEM determined it was necessary to impose a $\mathrm{CATCH}$ and RELEASE policy on all of the species you listed above, would you: PLEASE CHECK ONE OF THE FOLLOWING

Continue to fish the same amount you always have ..

Fish for other species

Stop marine recreational fishing all together

17) Do you currently practice catch and release? (Release fish alive that may be retained under current regulations)

Please Circle

(yes) (no) 
Answers to the survey questions are as follows:

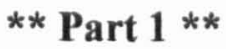

2) How long have you been a marine recreational angler? Mean of 28 years

8) How many times did you go marine recreational fishing last year?
From your own boat ...... Mean of 21 times

From another private boat Mean of 7 times

On a charter boat Mean of 1 time

On a party boat Mean of 7 times

From the shore Mean of 23 times

15) Which marine fishes do you target in the following areas:

Narragansett Bay The most popular species was Striped Bass followed by Bluefish.

Nearshore (0-3 miles) Same as above, as well as summer flounder.

Inshore (3-10 miles) Same as Narragansett Bay, as well as cod.

Offshore (11+ miles) The most popular species was tuna, followed by cod.

16) To demonstrate the economic impact of recreational fishing, approximately how much money did you spend in Rhode Island last year while marine recreational fishing: (Please note, these are the mean responses!)

Fishing gear $\$ \underline{437}$ Bait $\$ \underline{211}$ Fuel $\$ \underline{502}$

Docking/ramp fees $\$ \underline{338} \quad$ Lodging $\$ \underline{125}$

Charter/party boat fees $\$ 107$ Food $\$ 206$

17) To demonstrate the economic impact of recreational fishing, how much money do you spend on an average day of marine recreational fishing?

The mean response was $\$ 63$ 
1) What is your age? The mean response was 48.5 years old.

6) How many saltwater fly fishing rods do you own? Mean of 1.4

7) How many conventional saltwater fishing rods do you own? Mean of 9

8) Have you ever participated in a saltwater fishing tournament? (yes) (no) 70 percent responded "yes".

Please Circle

8a) If yes, which tournaments? The most frequently mentioned tournaments were club sponsored, followed by the Snug Harbor Striped Bass Tournament, The RI Striper Tourney and The RI Tuna Tourney.

9) Approximately what percentage of your marine recreational fishing time is spent on each of the following?

Saltwater flyfishing 8 percent

Saltwater rod and reel fishing 91 percent

Other (please explain) 1 percent line fishing.

10) Do you feel you catch (MORE, SAME, LESS) fish than other marine recreational fishermen? 30 percent felt more, 52 percent felt equal, and 18 percent felt they caught less.

11) Do you feel you are (MORE, SAME, LESS) skilled than other marine recreational fishermen? 30 percent felt more, 58 percent felt equal, and 12 percent felt they were less skilled.

12) For the mean responses to question 12 , please see page 38 of the text.

13) For the mean responses to question 13 please see page 39 of the text.

14) What is the most important marine recreational saltwater species you fish for in Rhode Island? Striped Bass.

Second most important? Bluefish. 
Third most important? Summer flounder.

15) If the Rhode Island Department of Environmental Management (DEM) determined it was necessary to REDUCE the number of fish you may keep from the species you listed above, would you: PLEASE CHECK ONE OF THE FOLLOWING

Continue to fish the same amount you always have... $\underline{83 \text { percent }}$

Fish for other species 15 percent

Stop marine recreational fishing all together 2 percent

16) If the Rhode Island DEM determined it was necessary to impose a CATCH and RELEASE policy on all of the species you listed above, would you: PLEASE CHECK ONE OF THE FOLLOWING

Continue to fish the same amount you always have .. 78 percent

Fish for other species 17 percent

Stop marine recreational fishing all together 5 percent

17) Do you currently practice catch and release? (Release fish alive that may be retained under current regulations). 22 percent reported they practiced catch and release. 


\section{BIBLIOGRAPHY}

Blalock, H. M. Jr. 1979. Social Statistics. 2d ed. McGraw-Hill, Inc.

Bryan, H. 1976. The Sociology of fishing: A review and critique. Pages 83-92 in H. Clepper, editor. Marine Recreational Fisheries. Sport Fishing Institute, Washington, D.C.

Bryan, H. 1977. Leisure Value Systems and Recreational Specialization: The Case of Trout Fishermen. Journal of Leisure Research, 9(1):174-187.

1982. A social science perspective for managing recreational conflict. Marine Recreational Fisheries, 7:15-22.

1983. The role of the fishery resource in the recreational angling experience. Report to the Sport Fishing Research Foundation, Washington, D.C.

Chipman, B. D., and L. A. Helfrich. 1988. Recreational Specialization and Motivations of Virginia River Anglers. North American Journal of Fisheries Management, 8:390-398.

Dawson, C. P., and B. T. Wilkins. 1980. Social Considerations Associated with Marine Recreational Fishing Under FCMA. Marine Fisheries Review, 42(12):12-17. 1981. Motivations of New York and Virginia Marine Boat Anglers and their

Preferences for Potential Fishing Constraints. North American Journal of Fisheries Management, 1:151-158.

Ditton, R. B. 1977. Human Perspectives in Optimum Sustainable Yield Fisheries Management. Marine Recreational Fisheries, 2:29-41.

1981. Social and Economic Considerations for Artificial Reef Deployment and Management. In Artificial Reefs: Conference Proceedings, edited by D. Y. Aska, 23-32. Florida Sea Grant College.

Ditton, R. B. and A. J. Fedler. 1989. Importance of Fish Consumption to Sport Fisherman: A Reply to Matlock et al. (1988). Fisheries, (Bethesda) 14(4):4-6.

Ditton, R. B., Loomis, D. K., and Choi, S. 1992. Recreational Specialization: Re-conceptualization from a Social Worlds Perspective. Journal of Leisure Research, 24(1):33-51. 
Ditton, R. B., Loomis, D. K., Risengoover, A. D., Choi, S., Osborn, M. F., Clark, J., Riechers, R., and Matlock, G. C. 1990. Demographics, Participation, Attitudes, Expenditures and Management Preferences of Texas Saltwater Anglers, 1986. Management Data Series No. 18, Coastal Fisheries Branch, Texas Parks and Wildlife Department, Austin, Texas.

Ditton, R. B., and S. M. Holland. 1984. Understanding Involved Fishermen: A Survey of the Gulf Coast Conservation Association. Department of Recreation and Parks, Texas A\&M University, College Station, Texas. 60pp.

Driver, B. L., and R. W. Cooksey. 1977. Preferred psychological outcomes of recreational fishing. Pages 27-40 in, Catch and Release fishing as a management tool: a national Sportfishing symposium. Arcata, California, Humbolt State University.

Driver, B. L., and R. C. Knopf. 1976. Temporary Escape: One Product of Sport Fisheries Management. Fisheries, 1(2):24-29.

Fedler, A. J. 1984. Elements of Motivation and Satisfaction in the Marine Recreational Fishing Experience. Marine Recreational Fisheries, 9:75-84.

Fedler, A. J., and R. B. Ditton. 1994. Understanding Angler Motivations in Fisheries Management. Fisheries, 19(4):6-13.

Federal Aid in Fish Restoration Act (16 U.S.C. 777-777k)

Fishery Conservation and Management Act of 1976, 16 U.S.C. section 1801-1882.

Gigliotti, L. M., and R. B. Peyton. 1993. Values and Behaviors of Trout Anglers, and Their Attitudes toward Fishery Management, Relative to Membership in Fishing Organizations: A Michigan Case Study. North American Journal of Fisheries Management, 13:492-501.

Graefe, A. R. 1981. Understanding Diverse Fishing Groups: The Case of Drum Fishermen. Marine Recreational Fisheries, 6:69-79.

Graefe, A. R., and A. J. Fedler. 1986. Situational and Subjective Determinants of Satisfaction in Marine Recreational Angling. Leisure Sciences, 8:275-295.

Hahn, J. 1991. Angler Specialization: Measurement of a Key Sociological Concept and Implications for Fisheries Management Decisions. Creel and Angler Survey in Fisheries Management. Proceedings of the American Fisheries Society Symposium 12:380-389. 
Hendee, J. C. 1974. A Scientist's Views on Some Current Wilderness Management Issues. Western Wildlands, Spring:27-32.

Holland, S. M., and R. B. Ditton. 1992. Fishing Trip Satisfaction: A Typology of Anglers. North American Journal of Fisheries Management, 12(1):28-33.

Hudgins, M. D., and W. D. Davies. 1984. Probability Angling: a Recreational Fishery Management Strategy. North American Journal of Fisheries Management, 4: 431439.

Jones III., John Paul. 1984. A spatially-varying parameter model of AFDC participation Empirical analysis using the expansion method. Professional Geographer, 36 (4): 455-461.

Loomis, D. K., and R. B. Ditton. 1987. Analysis of Motive and Participation Differences between Saltwater Sport and Tournament Fishermen. North American Journal of Fisheries Management, 7:482-487.

Matlock, G. C., G. E. Saul, and C. E. Bryan. 1988. Importance of Fish Consumption to Sport Fishermen. Fisheries, 13(1):25-26.

Moeller, G. H., and J. H. Engelken. 1972. What Fishermen Look for in a Fishing Experience. Journal of Wildlife Management, 36:1253-1257.

Peyton, R. B., and L. M. Gigliotti. 1989. The Utility of Social Research: A Re-examination of the East-Matagorda Bay Experience. Fisheries, 14(4):5-8.

Ross, M. R. 1991. Recreational Fisheries of Coastal New England. University of Massachusetts, Amherst. 279 pages.

Spaulding, I. A. 1970. Variation of Emotional States and Environmental Involvement During Occupational Activity and Sportfishing. VIR-1 Experiment Station Bulletin, 402, Kingston, R. I.

Spencer, P. D. 1993. Factors Influencing Satisfaction of Anglers on Lake Miltona, Minnesota. North American Journal of Fisheries Management, 13(2):201-209.

Spencer, P. D., and G. R. Spangler. 1992. Effect that Providing Information Has on Angler Expectations and Satisfaction. North American Journal of Fisheries Management, 12(2):379-385.

Sport Fishing Institute. The Quality of Fishing Reflects the Quality of Living. SFI bulletin (6) 1993. Washington, D. C.: The Sport Fishing Institute. 
Strauss, A. (1978). A Social World Perspective. Studies in Symbolic Interaction, 1, 119128.

Striped Bass Act of 1984, 98 Stat. 3187.

U.S. Department of Commerce. Marine Recreational Fishery Statistics Survey, Atlantic and Gulf Coasts, 1990-1991. National Marine Fisheries Service. Silver Spring, MD. 1992.

U.S. Department of Commerce. Status of Fishery Resources off the Northeastern United States for 1993. Northeast Fisheries Science Center. Woods Hole, MA. 1993.

U.S. Department of Commerce. Fisheries of the United States, 1994. National Marine Fisheries Service. Silver Spring, MD. 1995.

U.S. Department of the Interior, Fish and Wildlife Service and U.S. Department of Commerce, Bureau of the Census. 1991 National Survey of Fishing, Hunting, and Wildlife-Associated Recreation. U.S. Government Printing Office, Washington, DC. 1993.

Williams, E., T. Corey. 1994. Marine Recreational Fishing in Rhode Island. Rhode Island Sea Grant Fact Sheet P1364. Rhode Island Sea Grant Communications Office, Narragansett, Rhode Island. 